\title{
Copyright and Responsibility
}

\author{
Haochen Sun*
}

\begin{abstract}
This Article argues that the ethics of responsibility should be hailed as an intrinsic value undergirding copyright law. It considers how and why copyright law should be reformed to embrace a strong vision of copyright holders' responsibilities. To this end, it calls for a more dynamic vision regarding the nature of copyrighted works. A copyrighted work, as the Article shows, is not only the embodiment of its author's thought and personality, but also a social initiative in sharing intangible resources to promote creativity, shaping people's cultural power, and pursuing the quest for justice. These social values inherent in all copyrighted works provide the ethical justification for introducing responsibility into copyright and enforcing it as another core function of copyright law. Following the ethics of responsibility, copyright law should function to grant exclusive rights to copyright holders and also to impose social responsibilities on them.
\end{abstract}

\section{Table of Contents}

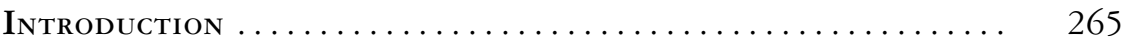

I. The Irresponsibility Mentality in Copyright law .... 269

A. Three Examples of the Irresponsibility Mentality of Many

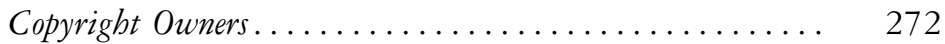

1. Expanding Copyrights................. 272

2. Narrowing Copyright Limitations .......... 274

3. Exaggerating Copyrights .............. 275

B. The Roots of the Irresponsibility Mentality ............ 278

* Assistant Professor of Law and Deputy Director of Law \& Technology Center, University of Hong Kong. For helpful conversations or generous comments on previous drafts, or both, I would like to thank: Gregory Alexander, Shyam Balganesh, Mario Biagioli, James Boyle, Irene Calboli, Anupam Chander, Albert Chen, Peter Lee, Sean Pager, Jed Purdy, Blake Ellis Reid, Madhavi Sunder, Talha Syed, Laura Underkuffler, Scott Veitch, Peter Yu, and Diane Zimmerman. I also received helpful comments and insights from the participants in the 2012 Intellectual Property Scholars Conference. 
II. Mainstreaming the Idea of Responsibility in Copyright

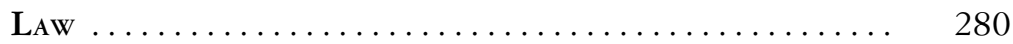

A. The Idea of Responsibility in Law................ 280

B. Overcoming Individualism .................... 282

1. Individualism in Copyright Law............ 282

2. Others' Contributions in the Creation and Dissemination of Works ................ 285

a. Others As Facilitators of Creating
Copyrighted Works ................... 285

b. Others As Collaborators in Disseminating Copyrighted Works ................. 288

3. Reciprocity-Based Responsibilities Law ....... 289

C. Promoting Copyright Holders' Role in Shaping Cultural Power .................................... 291

1. The Idea of Cultural Power ................ 291

2. The Role of Copyright Holders . ............. 292

3. The Role Responsibility of Copyright Holders... 294

D. Inducing Moral Deliberation about Social Justice........ 295

1. The Tension Between Copyright Protection and Social Justice ............................ 296

2. Copyright Owners' Responsibilities for Promoting Social Justice ......................... 299

E. Summary ............................. 300

III. Enforcing Responsibilities in Copyright Law ......... 300

A. The Place of the Responsibility Policy in Copyright Law .. 300

1. The Limits of the Copyright Clause and the First Amendment ....................... $\quad 300$

2. Mainstreaming the Responsibility Policy into Copyright Law ..................... 303

a. The Role of the Responsibility Policy ..... 303

b. Copyright Limitations as Copyright Holders' Responsibilities .................... 306

B. Promoting the Ethics of Responsibilities among Copyright

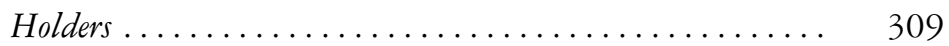

1. Negative Responsibilities ................. 309

a. The Basis of Negative Responsibilities ..... 310

b. The Enforcement of Negative Responsibilities

2. Collective Responsibilities ............... 313

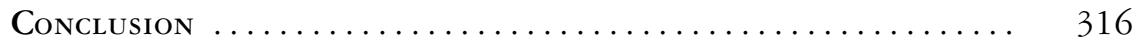


What is required of us now is a new era of responsibility-a recognition on the part of every American that we have duties to ourselves, our nation and the world; duties that we do not grudgingly accept but rather seize gladly, firm in the knowledge that there is nothing so satisfying to the spirit, so defining of our character than giving our all to a difficult task.

Barack Obama ${ }^{1}$

At the root of America's economic crisis lies a moral crisis: the decline of civic virtue among America's political and economic elite. . . . Without restoring an ethos of social responsibility, there can be no meaningful and sustained economic recovery.

Jeffery Sachs ${ }^{2}$

\section{INTRODUCTION}

Copyright law has long been dominated by the language of rights. The building blocks of the copyright system are designed to protect copyright owners' rights. ${ }^{3}$ However, legislators, judges, and policymakers rarely raise the question whether copyright owners should have responsibilities and how copyright law should enforce them. For example, amid the heated debate on the Google digital library project, few have asked whether copyright holders should have the responsibility to facilitate the creation of a public digital library. Given its unprecedented power to disseminate knowledge, the Google digital library project has been hailed as equivalent to the invention of the printing press. ${ }^{4}$ Yet, because the operation of its digital library in-

1 President Barack Hussein Obama, Inaugural Address (Jan. 20, 2009) (transcript available at http://www.whitehouse.gov/blog/inaugural-address).

2 Jeffrey D. Sachs, The Price of Civilization: Reawakening American VirTUE AND PROSPERITY 3 (2012).

3 See, e.g., Carys J. Craig, Copyright, Communication and Culture: ToWARDS A RELATIONAL THEORY OF COPYRIGHT LAW 2-3 (2011) (“[C]opyright is widely regarded as a system whose purpose is the protection of private, proprietary rights."); Roberta Rosenthal Kwall, The Soul of Creativity: Forging a Moral Rights LaW FOR the United States xiii (2010) (arguing that "copyright laws . . . are concerned generally with authors' rights.”); RoBERT P. MERGES, JusTIFying INTELlectual Property 5 (2011) (arguing that "the most important core principle" of property rights over intangible assets such as copyright is this: "[I]t assigns to individual people control over indivdiual assets. It creates a one-to-one mapping between owners and assets."); Christopher Kalanje, Leveraging Intellectual Property: Beyond the 'Right to Exclude', World Intell. Prop. Org., http://www. wipo.int/sme/en/documents/leveraging_ip.html (last visited Oct. 24, 2012) (arguing that the core of real property and intellectual property is the right to exclude).

${ }_{4}^{4}$ Mark Gregory, Google's Books Online under Fire, BBC News (May 24, 2005), http:// http://news.bbc.co.uk/2/hi/business/4576827.stm ("The head of Oxford Uni- 
volved unauthorized verbatim copying of copyrighted works, Google was sued for copyright infringement. ${ }^{5}$ Since then, the debate has been focused squarely on issues such as whether Google's digital library could constitute a fair use of copyrighted works ${ }^{6}$ and the validity of its dispute settlement agreement. $^{7}$ No serious discussion, however, has been raised to consider whether copyright holders have a social responsibility to assist in the creation of a public digital library.

The handling of the dispute between copyright holders and Google, therefore, reveals the lack of the principle of responsibility in the contemporary copyright system. Armed with the bundle of economic rights protected by copyright law, many copyright holders have taken for granted that they do not have responsibilities associated with their copyrights. For them, copyright simply denotes the absolutist notion of property, in which the owner enjoys "sole and despotic dominion which one man claims and exercises over the external things of the world, in total exclusion of the right of any other individual in the universe."

This Article seeks to address the irresponsibility mentality that modern copyright law has bred. To this end, it considers why the ethics of responsibility should be hailed as an intrinsic value undergirding copyright law. Following the ethics of responsibility, it argues that copyright law should function to grant exclusive rights to, and also impose social responsibilities on, copyright holders. ${ }^{9}$ It shows that the imposition of responsibilities on copyright holders stems from the human condition, namely that individuals are members of social groups. While copyrights play a crucial role in fostering a copyright holder's individuality, responsibilities are indispensable to a

versity's library service said the [Google] project could turn out to almost as important as the invention of the printing press.").

5 Author's Guild, Inc. v. Google Inc., No. 05-CV-8136 (S.D.N.Y. Sept. 20, 2005).

6 See, e.g., Matthew Sag, The Google Book Settlement and the Fair Use Counterfactual, 55 N.Y.L SCH. L. REv. 19 (2010) (arguing that the Google Books Library Project constitutes fair use); Diane Leenheer Zimmerman, Can Our Culture Be Saved? The Future of Digital Archiving, 91 MiNN. L. REv. 989, 1018-25 (2007). For the opinion holding that the Google project can not pass the fair use scrutiny, see Elisabeth Hanratty, Google Library: Beyond Fair Use?, 2005 Duke L. \& TecH. Rev. 10, ๆ 3 ("Without a significant change in interpretation of the law, it is unlikely that Google will be able to successfully claim its actions constitute fair use. . . ."); Siva Vaidhyanathan, The Googlization of Everything and the Future of Copyright, 40 U.C. DAvis L. REV. 1207, 1221-25 (2007).

7 See, e.g., Pamela Samuelson, The Google Books Search Settlement as Copyright Reform, 2011 WISC. L. REV. 479 (evaluating the validity of the settlement agreement).

8 William Blackstone, Commentaries on the Laws of ENGLANd 393 (1882).

9 See infra Part III. 
copyright holder's social membership. This Article argues that imposition of responsibilities plays three roles in nurturing the copyright holder's social membership: overcoming individualism, shaping cultural power, and inducing moral deliberation about social justice. ${ }^{10}$

The responsibility-based idea put forward by this Article makes two contributions to the copyright literature. First, the ethics of responsibility, as this Article will show, paves the way for us to reconsider the conventional wisdom about the nature of copyright law, which emphasizes the exclusive rights bestowed upon the individual copyright holder ${ }^{11}$ or the duties of others not to infringe those rights. ${ }^{12}$ In this Article, I argue that these conceptions of copyright law neglect the ethical ethos on which copyright holders' responsibilities should be based. The protection of copyright holders' rights is not and should not be the sole function of copyright law. Copyright law should be re-envisioned as a legal system that embodies the interrelated values of individual right (the copyright holder's right), collective right (the user's right), ${ }^{13}$ and responsibility (the copyright holder's responsibility).

10 See infra Part II.

11 The primary function of copyright law, according to the law and economics perspective and natural rights theory, is to grant and protect copyright holders' rights. Professors Landes and Posner, two pioneers of the economic analysis of copyright law, define copyright protection as "the right of the copyright's owner to prevent others from making copies. ...” William M. Landes \& Richard A. Posner, An Economic Analysis of Copyright Law, 18 J. LEgAL STUd. 325, 326 (1989) (emphasis added). By prioritizing the legal protection of the individual labor or personhood that is injected into copyrighted works, natural rights theorists have highlighted the role of copyright law in protecting copyright as an individual right. See generally, Wendy J. Gordon, A Property Right in Self Expression: Equality and Individualism in the Natural Law of Intellectual Property, 102 YALE L.J. 1533, 1544-1555 (1993); Justin Hughes, The Philosophy Of Intellectual Property, 77 GEO. L.J. 287, 296-306 (1988); William Fisher, Theories of Intellectual Property, in NEW Essays IN The Legal And Political Theory Of Property 168, 171-72 (Stephen R. Munzer ed., 2001).

${ }^{12}$ Professor Balganesh puts forth that the core function of copyright law is to enforce users' duty not to copy. Shyamkrishna Balganesh, The Obligatory Structure of Copyright Law: Unbundling the Wrong of Copying, 125 HARv. L. REv. 1664, 1665 (2012). He argues that copyright law's "exclusive rights framework functions almost entirely through its creation of an obligation not to copy original expression." $I d$. at 1665 . He further points out that "accepting that copyright's legal framework-as an obligatory system-speaks most directly to potential copiers rather than to creators." Id. at 1665-66.

13 See Haochen Sun, Fair Use as a Collective User Right, 90 N.C. L. REv. 125, 164 (2011). Other commentators have argued the case for including users' rights in copyright law. However, they do not define the nature of the user's right as a collective right. See generally L. Ray Patterson \& Stanley W. Lindberg, The Na- 
In addition to the above proposal, I further argue that the strategies that make copyright law more accommodative to the ethics of responsibilities should also be used to reshape the Copyright Act into a more socially viable legal instrument. Recently, leading copyright scholars such as Professors Jessica Litman, ${ }^{14}$ William Patry, ${ }^{15}$ and Pamela Samuelson, ${ }^{16}$ have demonstrated the urgency of, and made concrete proposals for, amending the Copyright Act, as it has become copyright holder-centric, obsolete, and over-complicated in the digital age. While I concur with these proposals, in this Article I put forward a new direction in which the reform of copyright law should proceed. I consider why the law should require copyright holders to take affirmative actions to address responsibilities that ought to be within the ambit of copyright law. Such a critical assessment would contemplate the renewed moral sentiments and political environment necessary to make copyright law adequately responsive to societal needs. ${ }^{17}$

This Article is divided into three parts. Part I reveals a pervasive irresponsibility mentality among many copyright holders. It further examines the roots of the irresponsibility mentality. Part II considers the ethical basis for imposing responsibilities on copyright holders. It shows that a copyrighted work is not only the embodiment of its author's thought and personality, but also a social initiative in sharing intangible resources to promote creativity, shaping people's cultural power, and pursuing the quest

TURe Of Copyright: A LAw Of Users' Rights 3-4 (1991) (stating that copyright should be viewed "as a law for consumers as well as for creators and marketers"); Julie E. Cohen, The Place of the User in Copyright Law, 74 Fordham L. Rev. 347 (2005); Abraham Drassinower, Taking User Rights Seriously, in IN The Public INterest: The Future Of Canadian Copyright Law 462 (Michael Geist ed., 2005); Niva Elkin-Koren, Making Room for Consumers Under the DMCA, 22 BERKELEY TECH. L.J. 1119 (2007) (discussing the rights of information consumers); Wendy J. Gordon \& Daniel Bahls, The Public's Rights to Fair Use: Amending Section 107 to Avoid the "Fared Use" Fallacy, 2007 Utah L. Rev. 619 (2007); Joseph P. Liu, Copyright Law's Theory of the Consumer, 44 B.C. L. REv. 397 (2003).

14 Jessica Litman, Real Copyright Reform, 96 Iowa L. REv. 1, 16 (2010) (discussing the weaknesses of the copyright system).

15 William Patry, How to Fix Copyright (2012).

16 Pamela Samuelson, Preliminary Thoughts on a Copyright Reform Project, 2007 UTAH L. REV. 551 (2007).

17 See Madhavi Sunder, IP 3 , 59 Stan. L. Rev. 257, 332 (2006) ("We should not fear the rise of new theoretical justifications for creating intellectual property rights - or for limiting them. There is much to be gained from articulating competing descriptive and normative visions of intellectual property, particularly those that challenge the historical distribution of the power to make and control cultural meaning."). 
for justice. It then argues that copyright law should have dual functions: protecting copyright holders' rights and enforcing their responsibilities.

Part III further explores the extent to which the ethics of responsibility can be translated into legal rules in copyright law. It shows that this transition should involve two crucial steps of implementation. First, legislators and regulators should promote the responsibility policy among copyright holders. In particular, they can use the responsibility policy to deal with the limitations on the extent to which the First Amendment and the Copyright Clause of the U.S. Constitution can protect the public interest in accessing copyrighted works. Second, the fair use exception should be redefined as a copyright holder's responsibility to accommodate fair uses of his or her works. Part III also discusses the specific negative and collective responsibilities that should be imposed on copyright holders.

\section{The Irresponsibility Mentality in Copyright law}

Law protects rights, but it also enforces responsibilities. It regulates human affairs through rules that require people to enjoy their freedoms and exercise their rights in responsible ways. ${ }^{18}$

For example, property law has a body of doctrines that require property owners to act responsibly toward their neighbors and the public at large. ${ }^{19} \mathrm{It}$ prohibits a property owner from causing both private nuisances that would interfere with another owner's peaceful enjoyment of his property and public nuisances that would harm the public interest. ${ }^{20}$ Other property doctrines,

18 See Jules L. Coleman, Beyond the Separability Thesis: Moral Semantics and the Methodology of Jurisprudence, 27 Oxford J. Legal STUd. 581, 584 (2007) ("Law regulates human affairs by rules that are reasons for acting. In that sense, governance by law necessarily respects the capacity of those to whom its directives are addressed to act on the basis of reasons.").

19 Property law has expressly embraced the ancient maxim sic utere tuo ut alienum non laedas ("use your land in such a way as not to injure the land of others") as a guiding principle in addressing property disputes. See Elmer E. Smead, Sic Utere Tuo Ut Alienum Non Laedas: A Basis of the State Police Power, 21 Cornell L. Q. 276, 277 (1936). Professor Alexander argues that "[m]odern property law imposes a wide range of obligations on owners." Gregory S. Alexander, The Social-Obligation Norm in American Property Law, 94 Cornell L. Rev. 745, 754 (2009).

20 Joseph William Singer, Introduction to Property 105-21 (2001) (explaining private and public nuisance doctrines as limitations on property rights that enforce property owners' responsibilities). Property law penalizes owners of factories that pollute water and/or air in an entire community, motels that serve as site for prostitution or lewd dancing, stores that sell pornography, and houses in which illegal drugs are sold. In these cases, public nuisances caused by irresponsible uses of property "injuriously affec[t] the safety, health, or morals of the public . . .." 
such as the eminent domain power ${ }^{21}$ and the public trust doctrine, ${ }^{22}$ are also designed to promote responsible property use. Interestingly, a vibrant discussion about the idea of responsibility has flourished in property literature, directing people to re-envision the role of property protection in fostering social dynamics. ${ }^{23}$

Copyright is one facet of property law, which as a system is designed to entitle owners to have exclusive control over tangible and intangible resources. However, the corresponding idea of responsibility is poorly incorporated into copyright law. Copyright statutes and judicial decisions rarely use responsibility as a guiding principle for dealing with copyright disputes. Worse still, only scant attention has been paid to the copyright holder's responsibilities in the vast copyright literature. ${ }^{24}$ Professor Jacqueline Lipton is one of the few scholars who argues that, "governments who create, support, and enforce information property," should also, "create, support, and enforce concurrent affirmative duties imposed on relevant right holders." 25 She advocates using lessons from property law to impose duties on copyright holders. ${ }^{26}$ But copyrights differ from real property rights: the former protect the intangible expression of ideas while the latter protect tangible objects. Thus, questions still remain as to why the obligatory scheme in property law

Commonwealth v. S. Covington \& Cincinnati St. Ry. Co., 205 S.W. 581, 583 (1918).

${ }^{21}$ See Alexander, supra note 19, at 775 (justifying the government's eminent domain power to force the sale of private property by regarding the eminent domain power as "an aspect of the social obligation inherent in private ownership.").

${ }^{22}$ See Haochen Sun, Toward a New Social-Political Theory of the Public Trust Doctrine, 35 Vт. L. REv. 563, 603 (2011) (arguing that the public trust doctrine "relies on social responsibilities that promote the stewardship ethic to protect collective rights over public space.").

${ }^{23}$ See, e.g., Eric t. Freyfogle, On Private Property: Finding Common Ground on the Ownership of Land (2007); Eric T. Freyfogle, The Land We Share: Private Property and the Common Good (2003); Joseph William Singer, Entitlement: The Paradoxes of Property (2000); Laura S. UnderkufFler, The Idea of Property: Its Meaning and Power (2003); Alexander, supra note 19, at 775; Jennifer Nedelsky, Reconceiving Rights as Relationship, 1 Rev. ConST. STud. 1, 16 (1994); Eduardo M. Peñalver, Property as Entrance, 91 VA. L. Rev. 1889 (2005); Jedediah Purdy, A Freedom-Promoting Approach to Property: A Renewed Tradition for New Debates, 72 U. CHI. L. REv. 1237 (2005).

${ }^{24}$ See, e.g., Roberta Rosenthal Kwall, The Author as Steward "For Limited Times," 88 B.U. L. Rev. 685, 705 (2008) (reviewing Lior Zemer, The IdeA of AuthorSHIP IN COPYRIGHT (2007), and pointing out that "the concept of 'duty' is not one that has received explicit attention in copyright circles . . ..").

25 Jacqueline Lipton, Information Property: Rights and Responsibilities, 56 FLA. L. REV. 135, 190 (2004).

${ }^{26}$ Id. at $165-81$. 
should be necessarily introduced into copyright law. Professors Roberta Rosenthal Kwall ${ }^{27}$ and David Vaver ${ }^{28}$ also discuss the possibility of channeling responsibility into copyright law and emphasize the value of responsibilities. But, they do not explain the larger theoretical basis, in particular the ethical justification, for imposing responsibilities on copyright holders.

The underutilization or near absence of responsibility in the theory and practice of copyright law and ethics has bred a widespread irresponsibility mentality ${ }^{29}$ among many copyright owners. Owners actively assert their copyrights, but barely talk about their responsibilities. William Patry, a leading scholar and practitioner in copyright law, bluntly describes the irresponsibility mentality as follows:

Copyright owners ... only speak in terms of the advantage of property rights, and never the burdens that necessarily go with property ownership. Such cherry-picking of only those things that you like isn't the way our legal system works. ... Although copyright owners routinely invoke property as "one of the basic tenets of a free society," they ignore the more fundamental tenet-the obligation of all citizens, including copyright owners, to society. . . Copyright owners also ignore that what they regard as a right is instead a government grant specifically for the benefit of society, not authors. ${ }^{30}$

The above statement demonstrates the fact that responsibility has become a "sunset" concept in the realm of copyright law and ethics. This section first discusses three examples of the irresponsibility mentality in which copyright owners use the language of rights and its rhetorical power to water down their responsibilities. The remainder of this section then ex-

27 Kwall, supra note 24, at 703-04 (elaborating on an understanding of "the colloquial author as a steward of her work," and suggesting that this understanding is "consistent with the view that copyright ownership involves duties to the public as well as rights in the work.").

${ }^{28}$ David Vaver, Copyright and the Internet: From Owner Rights and User Duties to User. Rights and Owner Duties?, 57 CASE W. REs. L. Rev. 731, 750 (2007) ("We should recognize that copyright owners have duties as well as rights. Among these duties are the provision of fair access to content at fair and non-discriminatory prices.").

29 See generally Scott Veitch, LAw ANd Irresponsibility: ON the LegitimaTION OF HuMAN SuFfERING 72 (2007) (emphasis in original) ("Immunised by the mechanisms of responsibility transference, underpinned by the naturalised economic realm of rights to private property upheld at almost any cost by state institutions, the irresponsible mentality appears not only as widely prevalent, but as legitimate. And such organized irresponsibility and legitimised immunities are call the law."”).

30 William Patry, Moral Panics and the Copyright Wars 123 (2009). 
plains what factors have operated to condone or even encourage the irresponsibility mentality among many copyright owners.

\section{A. Three Examples of the Irresponsibility Mentality of Many Copyright Owners}

\section{Expanding Copyrights}

Copyright-based industries have strived to strengthen copyright protection during the past few decades. Their aggressive lobbying efforts have led Congress to repeatedly amend the Copyright Act. For example, the Copyright Term Extension Act (CTEA) ${ }^{31}$ epitomizes how the copyright-based industry has been expanding the scope of copyrights. ${ }^{32}$ In 1998, Congress adopted the CTEA to give a twenty-year extension of copyright terms prospectively and retroactively. The retroactive extension of copyright terms, in particular, has pulled the works that were already or about to be out of copyright protection back under proprietary control. ${ }^{33}$ If the extension had not been made, these contents traditionally recognized as public property ${ }^{34}$ would have remained free for the public to use.

31 Sonny Bono Copyright Term Extension Act of 1998, Pub. L. No. 105-298, 112 Stat. 2827 (1998) (codified as amended at 17 U.S.C. $\$ \$ 101,108,203,301-04$ (2006)).

32 See Lawrence Lessig, Free Culture: The Nature and Future of CreaTIVITY 218 (2005) (noting that more than two-thirds of the original sponsors of CTEA in the House and Senate received contributions from Disney and that "Disney is estimated to have contributed more than $\$ 800,000$ to reelection campaigns in the 1998 cycle."); Christina N. Gifford, The Sonny Bono Copyright Term Extension Act, 30 U. MEM. L. REv. 363, 385-86 (2000) ("In fact, ten of the thirteen sponsors of the bill in the House received contributions from Disney, and eight of the twelve sponsors in the Senate were given money by Disney's political action committee. Disney also made a $\$ 20,000$ donation to the National Republican Senatorial Committee two weeks after Senate Majority Leader Trent Lott signed the bill. Other notable lobbyists included the Gershwin family, whose copyright on George Gershwin's 'Rhapsody in Blue' was due to expire in 1999, and other acclaimed artists like Bob Dylan and Quincy Jones.”).

33 Under the retroactive extension, works copyrighted in 1923 and timely renewed will not enter the public domain until 2018, assuming there are no further extensions.

34 See, e.g., Merriam v. Holloway Pub. Co., 43 F. 450, 451 (1890) ("When a man takes out a copyright, for any of his writings or works, he impliedly agrees that, at the expiration of that copyright, such writings or works shall go to the public and become public property ....."); Merriam v. Famous Shoe \& Clothing Co., 47 F. 411,413 (1891) ("[A]s the copyright on that edition has expired, it has now become public property. Any one may reprint that edition of the work . . ..”). 
The passage of the CTEA evinced the irresponsibility mentality championed by the copyright-based industry. Throughout its legislative history, the Congressional hearings were dominated by pro-copyright testimonies. The representatives from copyright-based industries argued for the extension of copyright terms by twenty years based on a need to provide economic incentive to produce and disseminate new works and to keep up with the term extension in the European Union. ${ }^{35}$ The legislative process of the CTEA, however, showed that its extension of copyright terms was adopted purely to benefit existing copyright holders, especially big entertainment companies. ${ }^{36}$ Heavily influenced by the rhetoric for stronger copyright protection, Congress did not consider whether the CTEA would substantively serve the public interest. Testimonies delivered before Congress were predominantly from representatives sent by the copyright-based industry who failed to furnish any evidence the CTEA would provide creators more incentive to produce and disseminate more works for the public. ${ }^{37} \mathrm{~A}$ brief signed by seventeen economists, including five winners of the Nobel Prize in Economics, however, shows that the copyright-based industry had indeed exaggerated the role of copyright term extension in incentivizing the production and dissemination of works. The brief concludes that there was no plausible claim that the twenty-year extension of the copyright term would do anything to incentivize the creation of works. ${ }^{38}$ Moreover, multiple studies have found that the CTEA may cause grave social harms. ${ }^{39}$ For example,

35 Eldred v. Ashcroft, 537 U.S. 186, 199-208 (2003).

36 See, e.g., LEssig, supra note 32, at 218.

37 See Dennis S. KarJala, Judicial Review of Copyright Term Extension Legislation, 36 LOY. L.A. L. REv. 199, 206-222 (2002) (concluding after review of the CTEA's legislative history that " $[\mathrm{a}]$ number of witnesses before Congress stated, in essence, that an extended term meant stronger copyright protection and that stronger protection would operate as an incentive to the creation of new works. No witnesses attempted to rebut the argument that the present value of the extended term to a current author is nil. No one testified that any particular author had decided against undertaking the creation of a new work that he would have undertaken had the prospective term been life plus seventy years instead of the pre-CTEA life-plus-50year term.").

38 Brief of George A. Akerlof et al. as Amici Curiae in Support of Petitioners at 10-12, Eldred v. Ashcroft, 537 U.S. 186 (2003) (No. 01-618), available at http:// cyber.law.harvard.edu/openlaw/eldredvashcroft/legal.html\#amici.

39 Richard Posner, Do Patent and Copyright Law Restrict Competition and Creativity Excessively?, The Becker-Posner Blog (Sept. 30, 2012, 10:30 PM), www.beckerposner-blog.com/2012/09/do-patent-and-copyright-law-restrict-competition-andcreativity-excessively-posner.html ("Apart from the fact that the present value of income received so far in the future is negligible, obtaining copyright licenses on very old works is difficult because not only is the author in all likelihood dead, but 
many economists have estimated that the CTEA would give rise to monopolistic control of information and thereby increase "the social cost of monopoly." 40

By aggressively lobbying Congress to pass the CTEA, the copyrightbased industry turned a blind eye to the social costs of the twenty-year extension of copyright terms. Their irresponsible assertion has made the length of copyright protection the most serious problem in copyright law. ${ }^{41}$

\section{Narrowing Copyright Limitations}

Copyright law itself contains safeguards aimed at preventing absolute protection of private ownership. By and large, these safeguards carve out limitations on the exclusive rights vested in creators. For example, the fair use doctrine allows the public to use reasonable portions of works for purposes such as "criticism, comment, news reporting, teaching, scholarship, or research." ${ }^{42}$ In addition, compulsory licensing schemes adopted in the U.S. Copyright Act allow relevant members of the public to use copyrighted works for statutorily designated purposes without their copyright holders' authorization, provided that users pay appropriate fees to copyright holders. ${ }^{43}$ Moreover, the first sale doctrine limits a copyright holder's right to control distribution of copies of the copyrighted work after they are sold to consumers. For instance, it allows purchasers to dispose of lawful copies in whatever fashion they wish, including by destruction, resale, donation, or lease. ${ }^{44}$ The rationale for the doctrine is "to prevent the copyright owner from restraining the free alienability of goods." ${ }^{45}$

While these safeguards do provide necessary breathing room for the public to use knowledge and information contained in copyrighted works, the copyright-based industry has stepped up efforts to narrow these limitations on copyright, curtailing the power of copyright limitations to constrain the exercise of copyrights. The passage of the Digital Millennium

his heirs or other owners of the copyright may be difficult or even impossible to identify or find.").

40 See, e.g., Akerlof et. al., supra note 38, at 10.

41 Posner, supra note 39 ("The most serious problem with copyright law is the length of copyright protection, which for most works is now from the creation of the work to 70 years after the author's death.").

4217 U.S.C. $\$ 107$.

43 See, e.g., 17 U.S.C. $§ 118$ (describing the use of copyrighted works in noncommercial broadcasting).

4417 U.S.C. $\$ 109$ (a).

45 Marshall A. Leaffer, Understanding Copyright Law, § 8.14[A], 310 (3d ed. 1999). 
Copyright Act (DMCA $)^{46}$ illustrates the aforementioned problem. Mainly demanded by the copyright-based industry, the DMCA was designed to significantly undercut the ability of copyright limitations to protect the public interest. ${ }^{47}$ Take the doctrine of fair use as an example. Fair use presupposes that the public at large first has free access to works and then makes decisions regarding whether they need to make fair uses. ${ }^{48}$ Free access to works shielded by technological measures, however, is no longer available for users under the DMCA. This is because the technological measures deployed by copyright holders fence them off from unrestricted access to works and the DMCA furnishes penalties against circumvention of those "digital fences." The DMCA further bars the manufacture and distribution of devices that are capable of circumventing these technological measures. ${ }^{49}$ By limiting free access, the DMCA has made it more difficult for the public to make fair use of works. ${ }^{50}$ While the copyright-based industry single-mindedly pushed Congress to pass the DMCA to strengthen copyright protection for their works, it ducked the issue as to whether the DMCA could seriously jeopardize the role of copyright limitations in promoting the free-flow of information and knowledge.

\section{Exaggerating Copyrights}

Many copyright holders have intentionally made extravagant copyright claims, overreaching the legitimate scope of their copyrights. Now seen as "copyrightfraud," 51 this type of irresponsible action takes the following four forms. First, there are copyright holders who have claimed copyright over uncopyrightable public domain materials. Copyright law only protects

46 Digital Millennium Copyright Act, Pub. L. No. 105-304, 112 Stat. 2860 (1998) (codified as amended in scattered sections of 17 U.S.C.).

47 See Neil Weinstock Netanel, Copyright's Paradox 69 (2008) (arguing that the DMCA "lays the legal groundwork for copyright holder control-over copying as well as access-untrammeled by the exceptions and limitations that are supposed to apply the copyright holder's rights")

48 See Jane C. Ginsburg, Copyright Legislation for the "Digital Millennium," 23 Colum.-VLA J.L. \& ARTs 137, 140 (1999) (observing that "it may be fair use to make nonprofit research photocopies of pages from a lawfully acquired book; it is not fair use to steal the book in order to make the photocopies.").

4917 U.S.C. $\$ 1201(\mathrm{~b})(1)(\mathrm{A})(2006)$.

50 See e.g., Jeff Sharp, Coming Soon to Pay-Per-View: How the Digital Millennium Copyright Act Enables Digital Content Owners to Circumvent Educational Fair Use, 40 Am. Bus. L.J. 1, 40 (2002).

51 Jason Mazzone, Copyfraud and Other Abuses of Intellectual PropERTY LAW (2011). 
works for a limited period of time. The term of copyright protection expires seventy years after the death of the author, making works public domain materials free for all to use from that point onward. However, publishers have claimed copyright over materials that are, by any reasonable person's view, public domain materials. For example, publishers have affixed copyright notices on books containing reprints of William Shakespeare's plays, The Federalist, and Charles Dickens's, Jane Austen's, and Benjamin Franklin's writings. ${ }^{52}$ The copyright notice routinely suggests that no part of those books may be reproduced without the prior written permission of the publisher. ${ }^{53}$ The same has occurred in the modern reprints of many other public domain works, such as sheet music and government documents. ${ }^{54}$ This problem is becoming worse in the digital environment. Although the Copyright Office has made it clear that "digitization . . . does not result in a new work of authorship," 55 copyright claims still have appeared frequently in the public materials that are digitized. For instance, ProQuest offers a subscription-based service containing digital versions of newspapers from the nineteenth century to the present. It affixes a copyright notice on every single newspaper page reproduced in its database. ${ }^{56}$

Second, invalid copyright claims have also been used as a means of stifling competition. The notice-and-takedown system created by the DMCA allows copyright holders to send notices to Internet service providers such as Google, YouTube, and Facebook to take down the holders' works posted by users online without their permission. One study found that fiftyfive percent of takedown notices sent to Google involved businesses targeting their competitors, ${ }^{57}$ and another study found that thirty percent of the notices included no valid copyright claim. ${ }^{58}$

Third, invalid copyright claims have also been used as a means to suppress speech. For example, Diebold, Inc., a manufacturer of electronic voting machines, sent many takedown notices to Internet service providers hosting leaked internal emails that revealed problems in Diebold's voting machines. The court concluded that "[n]o reasonable copyright holder could have be-

Id. at 9.

Id. at $9-10$.

${ }^{4} \mathrm{Id}$. at $10-11$.

${ }^{5} \mathrm{Id}$. at 11.

${ }^{56} \mathrm{Id}$. at 11.

57 Jennifer M. Urban \& Laura Quilter, Efficient Process or "Chilling Effects"? Takedown Notices Under Section 512 of the Digital Millennium Copyright Act, 22 SANTA Clara Computer \& High Tech. L.J. 621, 651 (2006).

${ }^{58}$ See also Mark A. Lemley, Rationalizing Internet Safe Harbors, 6 J. Telecomm. \& High Tech. L. 101, 114 (2007). 
lieved that the portions of the email archive discussing possible technical problems with Diebold's voting machines were protected by copyright." 59 Diebold had, therefore, knowingly used takedown notices when it knew that infringement had not occurred.

Fourth, many copyright holders have routinely exaggerated the scope of their economic rights as a way to prevent the public from making a fair use of their works. For example, the cautionary notice- "No part of this book can be reproduced without the permission of the publisher"-appears in almost every book published. Publishers also routinely limit users by stating that users may quote no more than a specified limited number of words, lines, or paragraphs from the book..$^{60}$ It seems that these publishers have turned a blind eye to the fair use doctrine, which sets no fixed limit on the amount users can copy and in fact allows the public to reproduce portions, or even the entire content, of the work. ${ }^{61}$

Similarly, big entertainment companies have exaggerated their economic rights and turned a blind eye to the fair use doctrine. In one case, in September 2007, Stephanie Lenz made a home video of her 13-month-old son dancing to "Let's Go Crazy" by Prince. Lenz posted the video on YouTube in order to share it with her family and friends. ${ }^{62}$ The video was twenty-nine seconds in length, and the song can be heard for approximately twenty seconds. Four months after the video was originally uploaded, Universal Music Group, which owned the copyrights to the song, ordered YouTube to remove the video. However, Universal used the notice-andtakedown procedure without taking account of Lenz's fair use right. De minimis use of this kind is routinely deemed fair use. ${ }^{63}$ Thus, Universal

59 Online Policy Grp. v. Diebold Inc., 337 F. Supp. 2d 1195, 1204 (N.D. Cal. 2004).

${ }^{60}$ Stephen Fishman, The Copyright Handbook: How To Protect \& Use WRITTEN WORKs 256 (9th ed. 2005) (“[A]lthough there is no legally established word limit for fair use, many publishers act as if there were one and require their authors to obtain permission to quote more [than] a specified number of words (ranging from 100 to 1,000 words).").

${ }^{61}$ See Campbell v. Acuff-Rose Music, Inc., 510 U.S. 569, 594 (holding that extensive copying for the purpose of parody is fair use); Sony Corp. of Am. v. Universal City Studios, Inc., 464 U.S. 417, 454-55 (1984) (holding that verbatim copying for time-shifting purposes is fair use).

${ }^{62}$ Lenz v. Universal Music Corp., 572 F. Supp. 2d 1150, 1152 (N.D. Cal. 2008).

${ }^{63}$ See Netanel, supra note 47, at 62 ("Under [the de minimis] doctrine, trivial copying of minute portions of existing works is deemed noninfringing despite nominally constituting fragmented literal similarity."). 
"acted in bad faith by issuing a takedown notice without proper consideration of the fair use doctrine." ${ }^{64}$

\section{B. The Roots of the Irresponsibility Mentality}

This section argues that the irresponsibility mentality was largely caused by the contemporary mode of the copyright system, in which legal norms primarily function to protect copyrights. ${ }^{65}$ The prevailing language in copyright law emphasizes the bundle of rights enjoyed by creators of works and those who acquire copyrights from original creators (like publishers). ${ }^{66}$ Due to this rights-based view, copyright owners enjoy absolute control of rights over their copyrighted works and possess the power to give others permission to use their works. For example, Blackstone claimed that an author "has clearly a right to dispose of [his work] as he pleases, and any attempt to take it from him, or vary the disposition he has made of it, is an invasion of his right of property." ${ }^{67}$

When individual rights occupy the center of the structure of copyright law, they are apt to prevail over the responsibilities that limit the ways in which copyright holders can exercise their bundle of rights. As Susan Sell points out, "The language of rights weighs in favor of the person claiming the right. The language of privilege weighs in favor of the person granting the privilege." ${ }^{\circ 8}$

${ }^{64}$ Lenz, 572 F. Supp. 2d at 1154-55; see Mom Sues Universal Music for DMCA Abuse, Elec. Frontier Found. (July 24, 2007), https://www.eff.org/deeplinks/ 2007/07/mom-sues-universal-music-dmca-abuse ("Universal must stop making groundless infringement claims that trample on fair use and free speech.") (quoting Electronic Frontier Foundation Staff Attorney Marcia Hoffman).

${ }^{65}$ See, e.g., Kwall, supra note 3, at xiii ("II]n many countries, copyright laws, which are concerned generally with authors' rights, emphasize author autonomy, personal connectedness to one's original work, and the integrity of the author's message through a doctrine known as moral rights."); Merges, supra note 3, at 5 ("The most important core principle of the institution of [intangible] private property is this: it assigns to individual people control over individual assets. It creates a oneto-one mapping between owners and assets."); Kalanje, supra note 3 (arguing that the core of real property and intellectual property is the right to exclude).

${ }^{66}$ See articles cited in footnote 3 .

67 William Blackstone, 2 Commentaries on the Laws of England 400, 405-06 (1766).

${ }^{68}$ Susan K. Sell, The Globalization of Intellectual Property Rights 51 (2003). As James Boyle points out, under the romantic vision of authorship, "[a]uthors tend to win," because this vision "provides economic analysis with at least the illusion of certainty." James Boyle, Shamans, Software and Spleens: LAW AND THE CONSTRUCTION OF THE INFORMATION SOCIETY 116 (1996). Mark Lem- 
As a result, the prevalence of the language of rights in copyright law gives copyright holders considerable room in which they can constantly highlight the need to protect their rights and duck any issues concerning their responsibilities. The remainder of this section will show the ways in which the use of the language of rights by the copyright-based industry has led legislators and judges to make a series of decisions that strengthen copyright protection and dismiss copyright holders' responsibilities.

First, the dominance of the copyright-based industry in the legislative process has persistently enlarged the scope of copyright owners' exclusive rights, giving them more power to tighten up the flow of informational resources. At the same time, the legislature has narrowed the limitations on those exclusive rights, which previously gave room for the public to use information contained in copyrighted works.

Second, the legislative expansion of copyright protection has been made without sufficient consideration of the social costs imposed on the public's access to and use of informational resources. In many cases, the legislative proposals submitted by industry lobbyists were overwhelmingly adopted by Congress without close scrutiny of their impact on public interests or close examination of viewpoints opposed to those held by copyrightbased industries. "Congress in effect agreed that if the industry representatives would invest the time and energy to develop a bill that all of them endorsed, Congress would refrain from exercising independent judgment on the substance of the legislation." ${ }^{\prime 69}$ In this one-sided process, many legislators have been preoccupied with the rhetoric that the stronger copyright protection would necessarily give copyright holders stronger economic incentive to produce and disseminate works, resulting in increased numbers and availability of works for the public. Yet, many legislators routinely shy away from asking whether this incentive-based assertion is plausible or not. Therefore, it is not surprising that legislative expansions of copyright "often

ley also notes that current trends in copyright law are "heavily skewed to protect the interests of corporations, not individual authors." Mark A. Lemley, Romantic Authorship and the Rhetoric of Property, 75 TEx. L. REv. 87/3, 882 (1997).

${ }^{69}$ Jessica Litman, Copyright Legislation and Technological Change, 68 OR. L. Rev. 275, 314-15 (1989) (footnotes omitted). Professor Litman also points out that "[m]uch legislation advances the agendas of private interest groups." Id. at 314; see also Jessica Litman, Copyright, Compromise and Legislative History, 72 Cornell L. REv. 857, 860-61 (1987) ("Indeed, the statute's legislative history is troubling because it reveals that most of the statutory language was not drafted by members of Congress or their staffs at all. Instead, the language evolved through a process of negotiation among authors, publishers, and other parties with economic interests in the property rights the statute defines."). 
consist of outright congressional rubber-stamping of industry-drafted legislative and committee reports." 70

Third, on the judicial side, many courts have not yet actively championed the ethics of responsibility. Instead, they have given strong support for the individualist notion of property that divorces the exclusive rights enjoyed by copyright holders from any responsibilities they ought to fulfill. For example, a federal district court asserted that "[c]opyright and trademark law are not matters of strong moral principle," but instead "economic legislation based on policy decisions that assign rights based on ... what legal rules will produce the greatest economic good for society as a whole." ${ }^{\prime 1}$ The quest for efficiency, as the court emphasized, is important. Yet the divorce of moral principles from the copyright adjudication process allows copyright holders to refrain from thinking about the ethical dimension of rights, in particular the impact of the enjoyment of their rights on others.

\section{Mainstreaming the Idea of Responsibility in Copyright Law}

The preceding Part discussed how and why the copyright system has caused the irresponsibility mentality problem. This Part considers the way in which this problem can be addressed. It argues the case for establishing another major function of copyright law: imposing responsibilities on copyright holders and effectively enforcing them. It shows that authors have dual identities as individuals and as social members. While copyrights are crucial for each author to achieve self-actualization as an individual, responsibilities are crucial for shaping each author as a social member. Section A of this Part explains how responsibility is encompassed in the law. Sections B, C, and $\mathrm{D}$ explore three ways in which responsibilities shape authors' social membership by situating authors in the larger network of (1) sharing cultural resources, (2) shaping cultural power, and (3) promoting social justice.

\section{A. The Idea of Responsibility in Law}

The human condition is such that each human being has dual identities: identities as an individual and as a social member. As an individual, each human being has unique self-worth and plans for achieving self-actuali-

\footnotetext{
${ }^{70}$ Netanel, supra note 47 , at 184.

71 Sarl Louis Feraud Int'l v. Viewfinder Inc., 406 F. Supp. 2d 274, 281 (S.D.N.Y. 2005), aff $d$ on this point, vacated on other grounds, 489 F.3d 474, 480 n.3 (2d Cir. 2007).
} 
zation. Meanwhile, each human being is also a social member. ${ }^{72}$ As a social member, each human being lives through different groups, organizations, and communities. Sharing vibrant public spaces is crucial for the human condition.

Fostering consciousness of one's rights and one's endeavors to exercise these rights allows personal individuality to flourish. ${ }^{73}$ Likewise, individuals' consciousness of their own respective responsibilities and endeavors to fulfill those responsibilities are also crucial for human flourishing. This is because, in contrast to the role of rights in fostering and promoting human individuality, responsibilities play an indispensible role in shaping each person's social membership. ${ }^{74}$

Responsibilities require each person to respond to the consequences caused by their actions. The attribution of responsibilities first depends on what a person has done or failed to do (causation). ${ }^{75}$ If causation is established, these responsibilities then generate legal or moral requirements for that person to meet (liabilities). For example, civil or criminal liabilities would be attributed to a person whose actions violated a law. Moral liabilities would be attributed to a person whose actions failed to meet moral requirements. In this way, responsibilities constitute limitations on the ways in which each person may exercise their individual rights. ${ }^{76}$ They require

72 As Hannah Arendt reminds us, "men, not Man, live on the earth and inhabit the world." Hannah Arendt, The Human Condition 7 (2d ed. 1998). No human being lives alone in the world. Rather, human beings live together in a common world, from birth to death.

73 See Haochen Sun, Designing Journeys to the Social World: Hegel's Theory of Property and His Noble Dreams Revisited, 6 Cosmos \& Hist.: J. NAT. \& Soc. Phil. 33, 44 (2010) (discussing the Hegelian notion that a human being has two inter-related identities of being - an individual and a social member).

${ }^{74}$ See generally Peter Cane, Responsibility in Law And Morality 54 (2002) ("Understanding responsibility, whether in law or morality, is not just a matter of knowing what it means to say we are responsible, but also of knowing what we are responsible for and what our prospective responsibilities are."); Christopher Kutz, Responsibility, in The Oxford Handbook of Jurisprudence And the PhilosoPHY OF LAw 548 (Jules Coleman \& Scott Shapiro eds., 2002) (arguing that the idea of responsibility plays an important role in operating interpersonal relationships).

75 See Michael S. Moore, Causation and Responsibility 1 (2009) ("Many of the liability rules [in law] are framed explicitly in terms of someone (usually the defendant) causing something (usually a harm).").

76 See, e.g., JoHn Dewey, Responsibility and Freedom, in ETHICs 436 (1908), available at http://teachingamericanhistory.org/library/index.asp?document $=2356$ ("In its external aspect, responsibility is liability. An agent is free to act; yes, butmust stand the consequences, the disagreeable as well as the pleasant, the social as well as the physical."). 
each person to care not only about their own individual interests, but also about the impacts of their actions or inactions on other social members. From this perspective, the idea of responsibility fosters a sense of social membership among persons and further nurtures the human capabilities to act as social members. As Peter Cane points out, "[t] the truth about responsibility grows, one assumes, out of a need or a desire to discover the meaning of life and what it means to be human."

Copyright is an individual right conferred on the creators of copyrighted works. But why should copyright holders be required to take on responsibilities? The following three sections will show that the imposition of responsibilities on copyright holders stems from the human condition that individuals are social members. While copyrights protected by law play a crucial role in fostering a copyright holder's individuality, responsibilities imposed by copyright law are indispensable for a copyright holder to nurture his or her social membership. The imposition of responsibilities plays three roles in nurturing the copyright holder's social membership. It helps copyright holders to (1) overcome individualism by responding to others' contributions to the creation and dissemination of copyrighted works, (2) perform their role of shaping people's cultural power properly, and (3) engage in moral deliberation about social justice. This ethical justification for incorporating responsibilities in copyright law echoes the recent calls from the academia that "[i]ntellectual property is about social relations and should serve human values." 78

\section{B. Overcoming Individualism}

This section first examines the relationship between individualism and copyright law through the idea of "romantic authorship." It then shows why creating and disseminating a copyrighted work is a socially conditioned process. Based on the ethical norm of reciprocity, the section argues that responsibilities should be imposed on copyright holders as a means of requiring them to respond to others' contributions to the creation and dissemination of their works.

\section{Individualism in Copyright Law}

The idea of "romantic authorship" has entrenched strong individualism in copyright law. It asserts that it is the authors' inner feelings and their

77 CANE, supra note 74 , at 283.

78 Sunder, supra note 17 , at 331. 
motivations to reveal those feelings to the world that give birth to their works. Therefore, authors are hailed as the sole creators of their works who should be given full credit for their contributions. The emphasis on romantic authorship has been widely accepted among many authors. For example, William Wordsworth states:

For all good poetry is the spontaneous overflow of powerful feelings: and though this be true, Poems to which any value can be attached were never produced on any variety of subjects but by a man who, being possessed of more than usual organic sensibility, had also thought long and deeply. ${ }^{79}$

Poems, according to Wordsworth, are composed solely through the fusion of a poet's emotions and his talent for literary expression. His observation, therefore, hails the ingenuity that creators inject in their works, isolating their works from the contributions made by others. ${ }^{80}$ The individualistic construction of authorship that Wordsworth championed applies to many other types of works protected by copyright law. ${ }^{81}$

As the idea of romantic authorship is "so widespread as to be nearly universal," 82 it has shaped copyright law as a legal tool functioning primarily to grant and protect individual rights over works of authorship to meet

79 William Wordsworth, Preface to the Second Edition of Several of the Foregoing Poems, Published, with an Additional Volume, Under the Title of "Lyrical Ballads.", in THE Poetical Works of Wordsworth 935 (Thomas Hutchinson ed., 1933).

${ }^{80}$ BoyLE, supra note 68, at 56 (arguing that the romantic vision of authorship perpetuates the notion that an author is "the genius whose style forever expresses a single unique persona. ..."); see also Keith Aoki, (Intellectual) Property and Sovereignty: Notes Toward a Cultural Geography of Authorship, 48 STAN. L. Rev. 1293, 1333-38 (1996); Peter Jaszi, On the Author Effect: Contemporary Copyright and Collective Creativity, 10 Cardozo ArTs \& ENT. L.J. 293, 293-95 (1992).

${ }^{81}$ Rosemary Coombe describes how this individualism-based idea influences the granting of rights in the law:

[T]he writer is represented in Romantic terms as an autonomous individual who creates fictions with an imagination free of all constraint. For such an author, everything in the world must be made available and accessible as an "idea" that can be transformed into his "expression", which thus becomes his "work." Through his labor, he makes these "ideas" his own; his possession of the "work" is justified by his expressive activity. So long as the author does not copy another's expression, he is free to find his themes, plots, ideas, and characters anywhere he pleases, and to make these his own (this is also the model of authorship that dominates Anglo-American laws of copyright).

Rosemary J. Coombe, The Cultural Life of Intellectual Properties: AuTHORSHIP, APPROPRIATION, AND THE LAW 211 (1998).

82 JaCk Stillinger, Multiple Authorship AND the Myth of Solitary Genius 183 (1991). 
the needs of individualistic impulses of possession and control. ${ }^{83}$ Rewarding authors for their creation of new works and protecting their interests are supposed to be the primary function of copyright law:

A conscientious author, who had a family to maintain, and a prospect of descendants, would regard the additional labour bestowed upon any considerable work he might have in hand, in the light of an insurance of money upon his own life for the benefit of his issue .... Deny it to him, and you unfeelingly leave a weight upon his spirits, which must deaden his exertions; or you force him to turn his faculties ... to inferior employments. ${ }^{84}$

Underlying Wordsworth's observation is a view of copyright protection as a response to a variety of purely individualistic needs; copyright law caters to these needs because the author is assumed to be the sole creator of a work and therefore deserves strong legal protection. As a result, they have created "the illusion of certainty" ${ }^{5}$ in copyright law: the legal definition of an "author" and a "copyrighted work" is simply determined by the author's contribution alone. Courts have recognized and enforced the individualistic impulses expressed by the romantic authorship idea ${ }^{86}$ For example, the Supreme Court defined "author" as "he to whom anything owes its origin; originator; maker; one who completes a work of science or literature."

83 Martha Woodmansee \& Peter Jaszi, Beyond Authorship: Refiguring Rights in Traditional Culture and Bioknowledge, in SCIENTIFIC Authorship: CREDIT AND INtellectual Property in Science 195, 195 (Mario Biagioli \& Peter Galison eds., 2002), available at http://www.case.edu/affil/sce/authorship-spring2004/article.pdf ("With its emphasis on originality and self-declaring creative genius, this notion of authorship has functioned to marginalize or deny the work of many creative people: women, non-Europeans, artists working in traditional forms and genres, and individuals engaged in group or collaborative projects, to name but a few.").

84 William Wordsworth, To the Editor of the Kendal Mercury, in The Prose Works of William Wordsworth 309, 312 (W.J.B. Owen \& Jane Worthington Smyser eds., 1974); see also Martha Woodmansee \& Peter Jaszi, The Law of Texts: Copyright in the Academy, 57 C. ENG. 769, 771 (1995) (pointing out that "[h]is exalted understanding of an author's calling leads Wordsworth to advocate an expansive view of copyright protection.").

85 As James Boyle points out, under the romantic vision of authorship, "[a]uthors tend to win," because it "provides economic analysis with at least the illusion of certainty." Boyle, supra note 68, at 116.

${ }^{86}$ Ryan Littrell, Note, Toward a Stricter Originality Standard for Copyright Law, 43 B.C. L. REv. 193, 194 (2001) ("[C]ourts approach copyright cases by applying their intuitive understanding of the author as a creator in the mold of eighteenth and nineteenth century Romantic authors .....”).

87 Burrow-Giles Lithographic Co. v. Sarony, 111 U.S. 53, 57-58 (1884) (emphasis added). 
"Writings" of "authors" were the "literary productions" of authors. ${ }^{88}$ The Supreme Court in Bleistein v. Donaldson Lithographing Company further stated that:

The copy is the personal reaction of an individual upon nature. Personality always contains something unique. It expresses its singularity even in handwriting, and a very modest grade of art has in it something irreducible, which is one man's alone. That something he may copyright unless there is a restriction in the words of the act. ${ }^{89}$

The Supreme Court reconfirmed in another watershed decision that copyrightable works "are original, and founded in the creative powers of the mind. The writings which are to be protected are the fruits of intellectual labor, embodied in the form of books, prints, engravings, and the like." 90

\section{Others' Contributions in the Creation and Dissemination of Works}

The conception of romantic authorship, however, does not comport with the reality of how copyrighted works are created and disseminated. ${ }^{91}$ As this section will show, the life of copyrighted works is socially conditioned. Authors' individual creative capabilities and efforts are indispensible for the creation and dissemination of works. But others' contributions to authors' works are crucial as well. Acting as facilitators, others provide cultural artifacts on which an author draw to create new works. Moreover, others also act as collaborators in disseminating meanings of an author's works.

\section{a. Others As Facilitators of Creating Copyrighted Works}

The creation of copyrighted works is a socially conditioned process. Authors must learn from existing cultural artifacts to create new works of

\footnotetext{
88 Id. at 58 .

89 Bleistein v. Donaldson Lithographing Co., 188 U.S. 239, 250 (1903).

90 Feist Publications, Inc., v. Rural Telephone Service Co., 499 U.S. 340, 346 (1991).

91 See Anupam Chander \& Madhavi Sunder, The Romance of the Public Domain, 92 CAL. L. REv. 1331, 1339 (2004) ("[S]cholars show that the romantic ideal ignores the actual process of creation, where individuals often work within corporate settings, an audience collaborates with authors to infuse work with meanings, and authors draw upon earlier creations."). See generally Peter Jaszi, Toward a Theory of Copyright: The Metamorphoses of "Authorship," 1991 Duke L.J. 455, 485-91; Martha Woodmansee, On the Author Effect: Recovering Collectivity, 10 Cardozo ARTs \& ENT. L.J. 279 (1992).
} 
authorship. Cultural artifacts include things such as symbols, genres of expression, and language. ${ }^{92}$ They are created by different generations of people and serve as cultural resources from which a human being can draw to connect his own inner cognitive world with the social world of other human beings and non-human objects. ${ }^{93}$ They may include non-copyrightable and copyrightable elements. For example, language is a cultural artifact free for everyone to use and is not protected by copyright law. On the other hand, there are cultural artifacts such as novels, poems, musical compositions, and paintings that may be subject to copyright protection.

Many writers, poets, songwriters, and visual artists have discussed the steps necessary to integrate existing cultural artifacts into works of authorship. First, authors must build the skills required to convey their thoughts through their works. Nobody is born as an author capable of creating copyrightable works. To become an author, one first needs to learn from copyrightable cultural artifacts. ${ }^{94}$ For example, by reading and appreciating others' fiction, one learns how to create characters, plots, settings, themes, and styles to write fiction. Similarly, by studying and appreciating others' paintings, one learns how to use colors and lines to paint. Without learning from others' works, an author cannot equip himself or herself with the skills needed to create new works of authorship. The copyrightable cultural artifacts needed in this process may be subject to copyright protection or may remain in the public domain, either because the term of copyright protection has run out or because the works were created before copyright laws were enacted.

Second, once having learned the required skills, authors also borrow from others' works. ${ }^{95}$ Literary and artistic borrowings are essential for pro-

92 See Carl Ratner, Historical and Contemporary Significance of Vygotsky's Sociobistorical Psychology, in Psychology: Theoretical-Historical Perspectives 455, 457 (Robert Rieber \& Kurt Salzinger eds., 2d ed. 1998), available at http://www.sonic. net/ cr2/sociohis.htm ("Cultural artifacts include signs, symbols, linguistic terms, and humanly produced objects and instruments such as chairs and books.").

${ }^{93} I d$. (pointing out that cultural artifacts structure human behaviors "by mediating the person's relation with the world ....").

${ }^{4}$ See, e.g., Julie E. Cohen, Creativity and Culture in Copyright Theory, 40 U.C. DAVIS L. REv. 1151, 1177-98 (2007) ("Because everyone is a user of artistic and cultural goods first and a creator second (if at all), an account of creativity constrained by situatedness must begin with users.").

95 See, e.g., Mark A. Lemley, The Economics of Improvement in Intellectual Property Law, 75 Tex. L. Rev. 989, 997 (1997) ("Creation does not occur in a vacuum. Rather, knowledge is cumulative — authors and inventors must necessarily build on what came before them."); Cohen, $i d$. at 1183 ("Across the spectrum of creative practice, manipulation of preexisting texts, objects, and techniques figures centrally 
moting the creativity of works created by the "borrower." This fact has been acknowledged and emphasized by many creators of works themselves. For example, T.S. Eliot states:

One of the surest tests [of the superiority or inferiority of a poet] is the way in which a poet borrows. Immature poets imitate; mature poets steal; bad poets deface what they take, and good poets make it into something better, or at least something different. The good poet welds his theft into a whole of feeling which is unique, utterly different than that from which it is torn; the bad poet throws it into something which has no cohesion. A good poet will usually borrow from authors remote in time, or alien in language, or diverse in interest. ${ }^{96}$

Similarly, Pablo Picasso said that " $(g)$ food artists copy; great artists steal." 97 To be sure, Eliot and Picasso are not saying that plagiarism should be tolerated. They merely assert that even very creative writers or artists need to borrow from others' works to create new, original works. ${ }^{98}$

Third, authors also learn from non-copyrightable cultural artifacts created by others to generate inspirations of expression. Non-copyrightable cultural artifacts are very broad in their scope, ranging from language to genres of expression to social traditions in which authors live. They are not copyrightable because they embody the basic media through which human beings perform expressive activities. Many authors have stressed the importance of this kind of learning experience. For instance, Susan Sontag admitted, "[i]f literature has engaged me as a project, first as a reader, then as a writer, it is an extension of my sympathies to other selves, other domains, other dreams, other worlds, other territories." 99 Sontag's acknowledgment of the roles of others in her work reflects the truism that creators of works need to draw on cultural artifacts such as language, ideas, culture, humor, and genre. Works are created in a rich interaction between a creator and the cultural and social context in which he or she is situated. ${ }^{100}$

in processes of cultural participation."); William W. Fisher III, Reconstructing the Fair Use Doctrine, 101 HaRv. L. Rev. 1659, 1729 (1988).

96 T.S. Eliot, Philip Massinger, in The SACRED WoOd 123, 125 (7th ed. 1972) available at http://www.bartleby.com/200/sw11.html.

97 Patry, supra note 30, at 73 (emphasis added) (quoting Pablo Piccaso).

${ }^{98} \mathrm{Id}$. at $72-74$ (summarizing the statements of talented authors to show they needed to borrow from others' works to create new works).

${ }^{99}$ Geoff Dyer, The diaries of a determined woman, OBSERVER, Jan. 3, 2009, at 19 (quoting Susan Sontag), available at http://www.guardian.co.uk/books/2009/jan/04/ reborn-diaries-susan-sontag-review.

${ }^{100}$ See Christian Stallberg, Towards a New Paradigm in Justifying Copyright: An Universalistic-Transcendental Approach, 18 Fordham Intell. Prop. Media \& Ent. L.J. 333, 337 (2008) ("Today it is a common occurrence that intellectual works 


\section{b. Others As Collaborators in Disseminating Copyrighted Works}

Authors' copyrighted works need their audiences to discover, reveal, and transform their meanings. Rather than acting as passive recipients, audiences of copyrighted works collaborate with authors to disseminate different layers of the meanings in copyrighted works. It is true that a copyrighted work would not have been created if its author did not create it the first place. But any work of authorship has no economic and cultural value unless its author discloses and circulates the work to an audience that understands and interprets the meaning of the work.

The collaborator status of the public as the audience of authors' works stems from the human condition that speech action can never occur in isolation. As Hannah Arendt pointed out, it is instead "surrounded by and in constant contact with the web of the acts and words of other men." 101 When an author makes his work available to the public, it is a speech action in which he is disseminating information to the public. This speech action then must be in constant contact with the intended audience. When the audience reads the work, they are doing more than just reading. Within the act of reading lies the reader's response to a given work. Literary theorists have defined the act of reading as a dialogue between the reader and the author of a text. The text is given meaning when the two dialogues interact with each other. Reading allows the reader to link the text to his or her personal experiences and to interpret the text through this lens:

The special meanings, and more particularly, the submerged associations that these words and images have for the individual reader will largely determine what the work communicates to him. The reader brings to the work personality traits, memories of past events, present needs and preoccupations, a particular mood of the moment, and a particular physical condition. ... These, and many other elements, interacting with the peculiar contribution of the work of art, produce a unique experience. ${ }^{102}$

Authors have concurred with the literary theory that elevates the status of their audiences to that of collaborators in disseminating the meanings of their works. Virginia Woolf pointed out that "[the reader] is a far better judge than the writer. Indeed, given time and liberty to frame his own opin-

never originate exclusively from the person authorship is attributed to. Instead, every author is integrated into the manifold social and cultural contexts from which he steadily borrows. Thus, creating intellectual works always means the appropriation of preceding ideas.").

101 ARENDT, supra note 72, at 188.

102 Louise M. Rosenblatt, Literature as Exploration 37 (1938). 
ion he is eventually an infallible judge." ${ }^{103}$ Marcel Duchamp argues that the audience of an artistic work ultimately determines the meaning of the work. According to Duchamp, the creative process continues even after the artist finishes his work because the art is also made through the admiration its audience has for it. ${ }^{104}$ The "artistic execution of the work rest[s] with pure intuition and cannot be translated into a self-analysis, spoken or written, or even thought out." ${ }^{105}$ Instead, it is the spectator who interprets and completes the creative process through "inner osmosis." ${ }^{106}$ During this process, "the spectator brings the work in contact with the external world by deciphering and interpreting its inner qualifications and thus adds his contribution to the creative act." ${ }^{107}$

\section{Reciprocity-Based Responsibilities Law}

As shown above, the creation and dissemination of works is socially conditioned. This defies the individualism embedded in the conception of romantic authorship and further raises the question of how authors should respond to the socially conditioned nature of their creative activities. The remainder of this section will argue that imposing responsibilities on authors based on the ethical norm of reciprocity would be an important way to make copyright law responsive to the socially conditioned nature of copyrighted works.

As an ethical norm, reciprocity teaches that "[w]e ought to be disposed, as a matter of moral obligation, to return good in proportion to the good we receive, and to make reparation for the harm we have done."108 Reciprocity promotes social membership by requiring people to take on two layers of responsibility. ${ }^{109}$ First, it requires people appreciate positive actions

103 Virginia Woolf et al., The Mrs. Dalloway Reader 12 (2003).

104 See Calvin Tomkins, The Bride \& The Bachelors: Five Masters of the Avant-GARDE 9 (1976) ("The artist, Duchamp said, is a 'mediumistic being' who does not really know what he is doing or why he is doing it.").

105 Marcel Duchamp, The Creative Act, Lecture at the Convention of the American Federation of Arts (Apr. 1957) (transcript available at http://www.wisdomportal.com/Cinema-Machine/Duchamp-CreativeAct.html).

106 Tomkins, supra note 104 , at 9.

107 Duchamp, supra note 105.

108 LAWRENCE C. BECKER, RECIPROCITY 3 (1986).

109 See Martha C. Nussbaum, Women and Human Development: The CaPABILITIES APPROACH 72 (2000) ("The core idea of [human nature] is that of the human being as a dignified free being who shapes his or her own life in cooperation and reciprocity with others, rather than being passively shaped or pushed around by the world in the manner of a 'flock' or 'herd' animal."). 
done by others for them. ${ }^{110}$ People need to be willing to recognize the benefits they have received from others and identify ways in which those benefits can promote their well-being. Indifference to others' positive actions will preclude any possibility of reflecting on the positive consequences of those actions. Second, reciprocity requires people to act in return for the benefits they received as a result of others' actions. Failure to return the favor would run counter to the ethical norm of reciprocity.

As previously discussed in this Part, human beings live in a social web of interdependence and cooperation. Reciprocity encourages one social member to respond to another's positive action with their own positive action. This kindness toward others' positive deeds requires a person to overcome selfish impulses and consider how he can reciprocate on the basis of others' interests. It then increases the predictability and stability of social bonds among members of the public. As a social norm, it provides predictability to the original positive actor that the outcome of his kindness will be reciprocated. Through this positive reinforcement and repeated practice of reciprocal actions, people will become more likely to initiate positive deeds for others and respond to others' positive deeds. As positive actions proliferate, social bonds stabilize. ${ }^{111}$

Following the norm of reciprocity, copyright law should require authors first to recognize others' contributions to the creation of their works. This recognition is of vital importance, as it prompts authors to better understand the creative process. ${ }^{112}$ Similarly, it may help judges and legislators to think about the nature of copyrighted works and make copyright law in accordance with the social nature of creativity and copyrighted works. ${ }^{113}$

Moreover, copyright holders' responsibilities under the reciprocity norm would further require them to consider what they ought to do in return for others' contributions to the creation and dissemination of works. According to Rawls, "[r]eciprocity is a moral idea situated between imparti-

110 See, e.g., David Schmidtz, The Elements of Justice 76 (2006) ("The art of reciprocity is partly an art of graciously acknowledging favors.").

111 Id. at 79 (arguing that reciprocity induces cooperation and "enables people to live together in mutually respectful peace.").

112 See, e.g., Northrop Frye, Anatomy of Criticism, Four Essays 96-97 (1957) ("Poetry can only be made out of other poems; novels out of other novels. All of this was much clearer before the assimilation of literature to private enterprise.").

113 As Justice Story commented, "in literature, in science and in art, there are, and can be, few, if any, things, which, in an abstract sense, are strictly new and original throughout. Every book in literature, science and art, borrows, and must necessarily borrow, and use much which was well known and used before." Emerson v. Davies, 8 F. Cas. 615, 619 (C.D. Mass. 1845) (No. 4436). 
ality, which is altruistic, on the one side and mutual advantage on the other." 114 Copyright holders' recognition of others' contributions to their works is an altruistic move. Yet it is not adequate to achieve mutual advantage since others have not yet benefited from copyright holders. To achieve mutual advantage, copyright holders need to think about what they should do to reciprocate others' contributions to their works.

\section{Promoting Copyright Holders' Role in Shaping Cultural Power}

The preceding section showed that, based on the norm of reciprocity, responsibilities can function to balance the individualism that is emphasized by the claim of romantic authorship. This section argues that the imposition of responsibilities upon copyright holders is further necessitated by copyright holders' role in shaping people's cultural power in social life. This section first discusses the idea of cultural power and its relationship to copyright protection. It then considers the "role responsibility" that should be imposed on copyright holders.

\section{The Idea of Cultural Power}

Culture defines who we are and what we can do. In this respect, we are only passive participants while culture actively shapes our lives. Being taught how to speak a language, interact with others, and appreciate things that are dear to us are all testaments to how culture affects the lives of individuals. ${ }^{15}$ However, we can simultaneously give internal meaning to various elements of culture. For example, through fashion, people constantly challenge acceptable practices and societal norms. Ultimately, people create new fashion trends that often revolutionize various aspects of our lives.

Cultural power makes it possible for us to be both shaped by culture and act as the meaning-makers. Two kinds of cultural power - the cultural

114 John Rawls, Justice as Fairness: A Restatement 77 (2001).

115 Such a phenomenon has been referred to as "the cultivation of individuals through the agency of external forms which have been objectified in the court of history" by sociologist Georg Simmel. Donald N. Levine, Introduction to GeorG Simmel, On Individuality and Social Forms, at ix, xix (Donald N. Levine ed., 1971); see also J. M. Balkin, Cultural Software: A Theory of Ideology 4-5 (1998) ("Each individual has a unique brain structure that is not merely the product of genetic inheritance but is shaped and organized in part by her experiences and activities, especially those in early childhood."); Barbara Rogoff, The Cultural Nature Of Human Development 3 (2003) ("Human development is a cultural process. As a biological species, humans are defined in terms of our cultural participation.”). 
power to discuss social issues and the cultural power to critique social issues - are crucial to individuals and society as a whole. In order to carry on discussions about social issues, we have to learn how to communicate and we need at least a slight comprehension of social issues. We cannot discuss religion or a literary work without any knowledge of such topics. Developing the enthusiasm to partake in discourse about various social issues, even if our interests are only peripheral, is another precondition for exercising the cultural power to discuss social issues.

Next is the cultural power to critique. The cultural power to critique empowers us to think critically about social issues and to depart from traditions that suppress creativity. A critical attitude toward orthodoxies leads to enhanced freedom and originality. The cultural power to critique also enables us to reject government propaganda and encourages us to become active participants of the policy-making process.

\section{The Role of Copyright Holders}

Authors participate in the cultural life of society by externalizing their thoughts and feelings through their works. They publish their works, making them available to the public. Their works contain discussions and reflections about issues relating to various aspects of social life. From this perspective, their works are crucial for members of the public to develop their cultural power.

First, works protected by copyright law play an important role in shaping people's cultural power to discuss social issues. Textbooks are essential for students at different levels of studies, equipping them with the necessary language skills and knowledge about various aspects of human life and society. Moreover, literary, musical, and artistic works such as novels, poems, songs, films, paintings, and sculptures are the necessary sources through which people in all walks of life achieve constant re-education by themselves. They help people learn about the cultural and political development of their society. Only after acquiring such knowledge can people enable themselves to participate in the discussion of social issues. ${ }^{116}$ The availability of works also improves people's willingness to discuss social issues. Copyrighted materials circulated by traditional media such as newspapers,

116 See Cohen, supra 94, at 1171 ("Both copyright scholars and cultural theorists understand cultural texts (including both conventional literary texts and all other forms of artistic expression) as performing a cultural transmission function."); Litman, supra note 18 , at 16 ("Reading, listening, and viewing have never been acts of purely passive absorption; they have always entailed meaningful creativity and imagination."); . 
magazines, and TV stations frequently reveal and examine new social issues and ignite public debate. Copyrighted materials circulated by new media such as blogs, Twitter, video-sharing sites, and online encyclopedias have created new means of engaging people to discuss social issues. ${ }^{117}$

Second, works protected by copyright law are also important for people to develop their cultural power to critique social issues. A wealth of literary, musical, and artistic works convey authors' moral reflections on the causes of massive catastrophes such as wars, famines, environmental pollution, or small-scale issues concerning how an individual can get along with his family, friends, or strangers. These works prompt their audiences to think about moral issues for their individual lives as well as society as a whole. From this perspective, copyrighted works promote humanitarian evolution by spreading ideas that expand the sphere of people's moral concerns about interpersonal relationships and the larger structure of human society. ${ }^{118}$ They not only impart knowledge to people to critique a wide range of social issues, but also encourage people to develop and express views that are critical of orthodoxies. Mario Vargas Llosa, a Nobel Laureate in Literature, wrote that "[n]othing awakens the critical spirit in a society as much as good literature." 119 According to Llosa, good literature can play such an important role because, "by awakening the critical spirit, [it] creates citizens who are more difficult to manipulate than in a society without literature and without good books." 120

The role of authors in shaping people's cultural power creates a new lens through which we can re-envision the nature of copyrighted works. Roland Barthes reminds us as follows:

117 Litman, supra note 14 , at 16 ("The widespread deployment of digital technology now allows readers, listeners, and viewers to express their creative readings in fixed form and share them with the world."); see generally PHILIP M. NAPOLI, Audience Evolution: New Technologies and the Transformation of Media AudienCEs (2011).

118 Peter Singer, Is Violence History?, N.Y. Times, Oct. 9, 2011, at BR1, available at http://www.nytimes.com/2011/10/09/books/review/the-better-angels-of-our-nature-by-steven-pinker-book-review.html? ref=books ("[T]he invention of printing, and the development of a cosmopolitan 'Republic of Letters' in the 17th and 18th centuries helped to spread ideas that led to the humanitarian revolution. That was pushed further in the 19th century by popular novels like 'Uncle Tom's Cabin' and 'Oliver Twist' that, by encouraging readers to put themselves in the position of someone very different from themselves, expanded the sphere of our moral concern.").

119 Luis Torres de la Llosa, Nobel laureate worries for literature in digital age, ABSCBN News (Oct. 8, 2010, 11:00 AM), http://www.abs-cbnnews.com/lifestyle/10/08/ 10/nobel-laureate-worries-literature-digital-age.

${ }^{120} \mathrm{Id}$. 
[A] text is made of multiple writings, drawn from many cultures and entering into mutual relations of dialogue, parody, contestation, but there is one place where this multiplicity is focused and that place is the reader, not, as was hitherto said, the author. The reader is the space on which all the quotations that make up a writing as inscribed without any of them being lost; a text's unity lies not in its origin but in its destination. ${ }^{121}$

Barthes's observation shows that the value of copyrighted works does not lie only in the degree to which authors' interests are protected. Their value should also be measured in terms of the ways in which they shape people's cultural power to discuss and critique social issues. This is because publicly available cultural resources are essential for the creation of copyrighted works, and such works are in turn essential for people to develop their cultural power. The dynamic public dimension of copyrighted works thus requires copyright law not to treat the value of works solely in terms of their copyright holders' interests. Rather, the law should highlight the public interest dimensions of copyright protection in fostering and promoting people's cultural power.

\section{The Role Responsibility of Copyright Holders}

The idea of role responsibilities, according to H. L. A. Hart, is crucial in shaping a "responsible person" who behaves properly. Hart justifies role responsibility in the following way:

A sea captain is responsible for the safety of his ship, and that is his responsibility, or one of his responsibilities. A husband is responsible for the maintenance of his wife; parents for the upbringing of their children . . . a clerk for keeping the accounts of his firm. These examples of a person's responsibilities suggest the generalization that, whenever a person occupies a distinctive place or office in a social organization, to which specific duties are attached to provide for the welfare of others or to advance in some specific way the aims or purposes of the organization, he is properly said to be responsible for the performance of these duties, or for doing what is necessary to fulfill them. Such duties are a person's responsibilities. ${ }^{122}$

Responsibility, as Hart shows, could be imposed on a person based on the role he or she plays in a social setting. A person occupies a specific position such as a sea captain, a husband, or a clerk. This socially identifiable

121 Roland Barthes, The Death of the Author, in Image-Music-Text (Stephen Heath ed., trans., 8th ed. 1968).

122 H.L.A. Hart, Punishment and Responsibility: Essays in the Philosophy OF LAW 212 (2d ed. 2008). 
position triggers corresponding responsibilities to benefit others who have relationships with the person in that role. If a person fails to fulfill the responsibility in proportion to his or her role, he or she would be held legally or morally accountable. Role responsibility, therefore, induces persons to think seriously about the specific roles they ought to occupy as social members and how to fulfill the corresponding responsibilities to play their roles well. Hart emphasizes this reflexive function of role responsibility. For example, he points out that "[a] responsible person is one who is disposed to take his duties seriously; to think about them, and to make serious efforts to fulfill them. To behave responsibly is to behave as a man would who took his duties in this serious way." 123

Therefore, authors' roles as social members participating in social life open up a new ethical dimension of copyright law. Individual rights over copyrighted works are designed to promote and protect authors' roles as individual proprietors. Individual rights have limited power in shaping authors' participation in social life. ${ }^{124}$ The imposition of role responsibilities upon authors can make copyright law function to shape the ways in which authors carry out their roles as social members. Authors' role responsibilities should center on the ways in which authors, by disseminating works that empower others to discuss and critique social issues, can help these members of the public to nurture and enhance their own cultural power in social life. In addition, copyright affects the ways in which cultural power is allocated among people. By conferring upon copyright holders the right to exclude others from using intangible assets under their proprietary control, copyright law affects how cultural exchanges and interactions among people occur, and whether or not they enhance their cultural power.

\section{Inducing Moral Deliberation about Social Justice}

This section argues that the need to induce moral deliberation about social justice among copyright holders further necessitates the imposition of responsibilities upon them. It shows that, as social members, copyright

123 Id. at 213.

124 Professor Carol Rose emphasized that a successful property system should have the educative function of guiding citizens to behave responsibly: "[P]roperty regimes ... induce the very qualities of cooperation, attentiveness to others, responsibility, and self-restraint that themselves are the prerequisites to the successful handling and trade of property. . . . All this suggests . . property as a keystone right, that is, as an educative institution." CAROL M. Rose, Property as the Keystone Right?, 71 Notre Dame L. Rev. 329, 364 (1996). 
holders can promote social justice by taking on the responsibilities that are relevant to their copyrighted works.

\section{The Tension Between Copyright Protection and Social Justice}

It is widely recognized that all human beings are equal individuals with equal worth. ${ }^{125}$ Yet, disparities exist in all modern societies. For example, income inequality exists in many societies and continues to worsen. ${ }^{126}$ Against this backdrop, social justice has been championed as a human value to minimize the impact unequal distribution of resources has on the disadvantaged. The following statement by John Rawls captures the essence of social justice as a fundamental human value:

Justice is the first virtue of social institutions, as truth is of systems of thought. A theory however elegant and economical must be rejected or revised if it is untrue; likewise laws and institutions no matter how efficient and well-arranged must be reformed or abolished if they are unjust. ${ }^{127}$

Hailed as a fundamental human value, social justice measures the degree of inequality a society accommodates through its institutions. It therefore defines the characters of a society in which people live. In general, it requires individuals and governments to make sustained efforts to combat inequalities. ${ }^{128}$ At the individual level, social justice requires that the advantaged be subject to appropriate redistributive mandates, diverting their resources to take care of the disadvantaged. At the social level, it requires

125 For example, Article 1 of the Universal Declaration on Human Rights states that, "[a]ll human beings are born free and equal in dignity and rights. They are endowed with reason and conscience and should act towards one another in a spirit of brotherhood." Universal Declaration of Human Rights, G.A. Res. 217 (III) A, U.N. Doc. A/RES/217(III) (Dec. 10, 1948).

126 See Ilyana Kuziemko and Stefanie Stantcheva, Our Feelings About Inequality: It's Complicated, available at opinionator.blogs.nytimes.com/2013/04/21/our-feelings-about-inequality-its-complicated/?ref=opinion ("Since the 1970s, income inequality in the United States has increased at a historic rate. In 1970, the richest 1 percent of Americans enjoyed 9 percent of total national pre-tax income. In 2011, by contrast, that share had risen to 19.8 percent.").

127 JOHn Rawls, A Theory OF Justice 3 (rev. ed. 1999).

128 According to the Rawlsian Difference Principle, "the higher expectations of those better situated are just if and only if they work as part of a scheme which improves the expectations of the least advantaged members of society." $I d$. at 65 . Rawls further explained that "[t]he intuitive idea is that the social order is not to establish and secure the more attractive prospects of those better off unless doing so is to the advantage of these less fortunate." $I d$. 
that the government take affirmative measures to nurture a just society. To this end, the government may redistribute resources owned by the advantaged to meet the needs of the disadvantaged.

Does copyright protection cause social inequality? If so, is there a general basis for imposing further responsibilities copyright holders the purpose of promoting social justice? This section answers each question in the affirmative. For example, the Uruguay Round Agreements Act ("URAA") 129 enacted by Congress in 1994, carries distributive consequences that have disadvantaged certain groups of content users. Section 514 of the URAA, codified in 17 U.S.C. $§ 104$ A and effective January 1, 1996, automatically restored copyright protection to certain foreign works in the public domain. Effective January 1, 1996, Section 514 automatically restored copyright protection to all works of foreign origin that were not yet in the public domain in their source countries, but that were in the public domain in the United States for specified reasons. ${ }^{130}$

17 U.S.C. $\S 104 \mathrm{~A}$ has caused social inequality in two ways. First, holders of copyrights over restored works can charge fees for works that consumers had previously used for free. Take orchestra groups as an example. Orchestras have two ways of performing a work in the public domain they can purchase the necessary sheet music or they can rent physical copies of the sheet music. ${ }^{131}$ There is only one option for performing a work under copyright protection - renting the sheet music. ${ }^{132}$ "Rental fees for a full orchestration of a copyrighted work can be $\$ 800$ or more for a single performance." 133 The cost will only go up for an orchestral group that requires a longer rehearsal period. ${ }^{134}$ Such rental fees can get extremely expensive for small orchestras. ${ }^{135}$ Since the passage of 17 U.S.C. $\S 104$ A, the price of a

129 See Uruguay Round Agreements Act of 1994, Pub. L. No. 103-465, § 514, 108 Stat. 4809, 4976 (1994) (codified at 17 U.S.C. § 104A (2006)).

${ }^{130}$ Foreign authors had no recourse for the lack of protection in years prior to $\S 104$ A's enactment. 17 U.S.C. $\$ 104 A(a)(1)$ (2006). They therefore enjoyed fewer total years of exclusivity than did their U.S. counterparts. Foreign works lacked protection in the United State for any of three reasons: (1) The United State did not protect works from the country of origin at the time of publication; (2) The United State did not protect sound recordings fixed before 1972; and (3) The United States did not protect works of an author who had failed to comply with U.S. statutory formalities. 17 U.S.C. $\S 104 \mathrm{~A}(\mathrm{~h})(6)(\mathrm{C})$ (2006).

131 Brief of the Conductors Guild \& the Music Library Ass'n as Amici Curiae Supporting Petitioners at 4, Golan v. Holder, 132 S. Ct. 873 (2012) (No. 10-545).

$$
\begin{array}{ll}
{ }_{132} I d . \\
{ }_{133} I d . \\
{ }_{134} I d . \\
{ }^{135} \text { Id. at } 5 .
\end{array}
$$


score of Shostakovich's Preludes and Fugues Op. 87 has risen by a multiple of seven. ${ }^{136}$ Peter and the Wolf, a popular orchestral piece for young children, can no longer publicly be performed without permission from the copyright holder. ${ }^{137}$ In this context, Justice Breyer criticized the passage of 17 U.S.C. $\S 104 \mathrm{~A}$. "If a school orchestra or other nonprofit organization cannot afford the new charges ... [t]hey will have to do without." ${ }^{138}$ That, however, would "aggravat[e] the already serious problem of cultural education in the United States." 139

Second, 17 U.S.C. $§ 104 \mathrm{~A}$ places on the general public a heavy burden of locating copyright holders of restored works to negotiate a license or a fee for using them. Orphan works are "works that appear to be 'in-copyright' but whose authors cannot be identified or located." ${ }^{140} 17$ U.S.C. $§ 104 \mathrm{~A}$ will exacerbate the orphan works problem. ${ }^{141}$ To license a copyrighted work, one must know the date and country of publication or creation and determine whether the work was under copyright protection in the country of origin at the date of restoration. ${ }^{142}$ Yet, finding the right holder after a work is restored from the public domain can be extraordinarily difficult, or impossible. ${ }^{143}$ This is especially problematic for many libraries. The restoration "affects potentially millions of works formerly in the public domain, many of which could be made available at the Internet Archive, on Wikimedia sites, in the HathiTrust Digital Library, or via myriad other libraries and digital repositories," in the nation. ${ }^{144}$ "In order to acquire and provide access to digital materials, libraries and digital repositories are dependent on reliable conclusions as to whether a work is in the public domain." ${ }^{145}$ The restoration will "force[ ] them to operate in a gray area, subject to real litigation concerns and subsequent chilling effects." 146 As a result, "libraries will simply not reproduce the material or make it available online until they

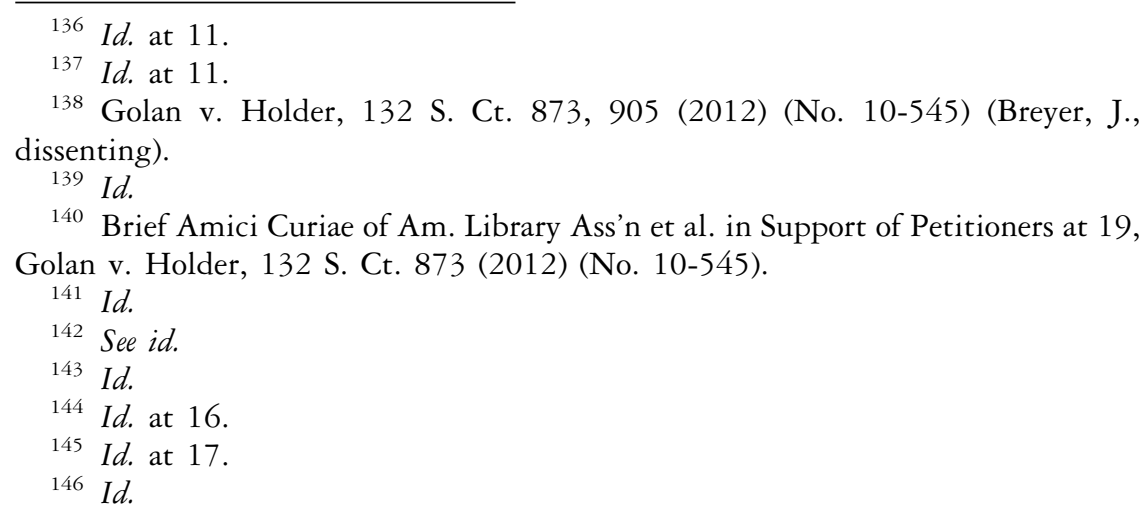


can be sure the copyright has expired - which may mean waiting for over a century." 147

\section{Copyright Owners' Responsibilities for Promoting Social Justice}

The above discussion showed the tension between copyright protection and the promotion of social justice in our society. One way of addressing the tension is to require copyright holders to undertake responsibilities to ease the burden that copyright protection places on the affected public. Central to social justice is how to allocate division of responsibilities in society. For instance, John Rawls states:

This conception [of justice] includes what we may call a social division of responsibility: society, the citizens as a collective body, accepts the responsibility for maintaining the equal basic liberties and fair equality of opportunity, and for providing a fair share of the other primary goods for everyone within this framework, while citizens (as individuals) and associations accept the responsibility for revising and adjusting their ends and aspirations in view of the all-purpose means they can expect, given their present and foreseeable situation. ${ }^{148}$

From the perspective of distributing responsibilities, social justice dictates that the benefits and burdens of social cooperation must be appropriately distributed among citizens. Rawls further states, "the principles of social justice ... provide a way of assigning rights and duties in the basic institutions of society and they define the appropriate distribution of the benefits and burdens of social cooperation." ${ }^{449}$

Within a system of social cooperation, copyright holders should be required to bear burdens in proportion to the benefits they receive from copyright protection. Ex post, copyright holders' burdens, or responsibilities, would require them to take action to mitigate social inequalities resulting from copyright protection. Ex ante, these responsibilities would require them to think about and respond to the ways in which copyright protection affects the distribution of social resources. Copyright holders should ponder the legitimacy of any initiative to strengthen the legal protection of copyrights from the perspective of social justice, in particular whether a socially beneficial distribution of benefits and burdens is achievable.

147 Id.

148 John Rawls, Social Unity and Primary Goods, in Collected Papers 359, 371

(Samuel Freeman ed., Harvard University Press, 1999).

149 RAWLS, supra note 127 , at 4. 


\section{E. Summary}

This Part showed that a copyrighted work is not only the embodiment of its author's thought and personality. Instead, these works are a social enterprise that arises from shared cultural resources, shapes cultural power, and promotes social justice. The social privilege inherent in all copyrighted works provides the ethical justification for introducing responsibility into copyright and enforcing it as another core function of copyright law. Following the ethics of responsibility, copyright law should function both to grant exclusive rights to copyright holders and to impose social responsibilities on them.

\section{Enforcing Responsibilities in Copyright Law}

Many ethical norms take effect only when they are translated into legal rules that create penalties for violations of their ethical mandates. The same should apply to the ethics of responsibility for copyright holders as discussed in the preceding Part. The Part that follows examines the extent to which the ethics of responsibility can be translated into legal rules in copyright law. It argues that this transition should involve two crucial steps of implementation. The first step deals with the assimilation of what I call the responsibility policy into copyright law. The second step involves applying the responsibility policy and the redefinition of the nature of copyright limitations in order to reform copyright law. The reform should introduce legal rules to enforce two kinds of copyright holders' responsibilities: negative responsibilities and collective responsibilities.

\section{A. The Place of the Responsibility Policy in Copyright Law}

\section{The Limits of the Copyright Clause and the First Amendment}

It is widely accepted that the Copyright Clause and the First Amendment lay the policy foundation for copyright law. The central policy embedded in the Copyright Clause is the mandate that copyright statutes should promote "the Progress of Science and useful Arts." ${ }^{150}$ However, such statutes cannot contravene the First Amendment. Thus, the limited term of copyright protection, the idea/expression dichotomy, and the fair use doc-

150 The Copyright Clause grants Congress the power "[t]o promote the Progress of Science and useful Arts, by securing for limited Times to Authors and Inventors the exclusive Right to their respective Writings and Discoveries." U.S. ConsT. art. I, $\S 8, \mathrm{cl} .8$. 
trine have been recognized as essential safeguards to make copyright law compatible with freedom of expression. ${ }^{151}$

However, both the Copyright Clause and the First Amendment have limitations as the policy bases of copyright protection. First of all, both of them only address state action, setting up a check on the governmental power to regulate informational resources. ${ }^{152}$ According to the state action doctrine, neither the Copyright Clause nor the First Amendment can directly apply to private action taken by the copyright holder to affect the public's access to and use of copyrighted materials. ${ }^{153}$ Thus, since the Copyright Clause and the First Amendment are not directly enforceable against copyright holders, they do not provide a legal basis to penalize the wrongdoings resulting from their irresponsible acts discussed in Part I.

Moreover, neither the Copyright Clause nor the First Amendment have acted as an effective check on the government in allocating proprietary control over informational resources through copyright regulation. ${ }^{154}$ For instance, the Supreme Court has stated that the Copyright Clause does not empower the judiciary to scrutinize whether a state action to expand copyright protection is valid under the Clause. "[The Court is] not at liberty to second-guess congressional determinations and policy judgments of this or-

151 E.g., Harper \& Row Publishers, Inc. v. Nation Enters., 471 U.S. 539, 560 (1985) (emphasizing "the First Amendment protections already embodied in the Copyright Act's distinction between copyrightable expression and uncopyrightable facts and ideas, and the latitude for scholarship and comment traditionally afforded by fair use. ...”).

152 For example, as the Supreme Court held in Wooley v. Maynard, "the right of freedom of thought protected by the First Amendment against state action includes both the right to speak freely and the right to refrain from speaking at all." 430 U.S. 705, 714 (1977).

153 See Lugar v. Edmondson Oil Co., 457 U.S. 922, 936 (1982) ("Careful adherence to the 'state action' requirement preserves an area of individual freedom by limiting the reach of federal law and federal judicial power."); see also Wilson R. Huhn, The State Action Doctrine and the Principle of Democratic Choice, 34 HofsTra L. REV. 1379, 1388 (2006) (“[T]he Constitution does not purport to determine how one person is to treat another. So far as the Constitution is concerned, one individual may steal the possessions of another, assault another person, even commit murder, and it is not a violation of the Constitution.").

${ }^{154}$ See, e.g., Netanel, supra note 47 (proposing that copyright law should be subject to First Amendment scrutiny); Robert P. Merges, One Hundred Years of Solicitude: Intellectual Property Law, 1900-2000, 88 CAL. L. Rev. 2187, 2239 (2000) ("The point remains the same: in an age of increasing 'statutorification' in intellectual property law, the system needs a counterweight where the legislative process is skewed. The [Copyright] Clause of the constitution, long dormant, seems the best candidate."). 
der, however debatable or arguably unwise they may be."155 Without any institutional check on the state power to allocate informational resources, the Copyright Clause has instead become the ground on which the legislature can strengthen copyright protection, ${ }^{156}$ which chiefly caters to the private interest of copyright holders and brings about marginal or no benefits for the public interest in regards to learning and knowledge sharing.

Furthermore, both the rights to free speech $^{157}$ and to property ${ }^{158}$ are considered fundamental to citizens. This equal doctrinal status renders it impossible for the right to free speech to gain primacy over a property right, such as copyright. ${ }^{159}$ Thus, in allocating informational resources through copyright law, the government may not presumptively give primacy to free

155 Eldred v. Ashcroft, 537 U.S. 186, 208 (2003). The Court also concluded, "it is generally for Congress, not the courts, to decide how best to pursue the Copyright Clause's objectives." Id. at 212; see also Sony, 464 U.S. 417, 429 (1984) (" $[\mathrm{I}] \mathrm{t}$ is Congress that has been assigned the task of defining the scope of [rights] that should be granted to authors or to inventors in order to give the public appropriate access to their work product.").

156 See Dotan Oliar, Making Sense of the Intellectual Property Clause: Promotion of Progress as a Limitation on Congress's Intellectual Property Power, 94 GEO. L.J. 1771, 1837 (2006) ("[E]ven if an Eldred II were filed tomorrow, we would still be unlikely to see the Supreme Court writing a manifesto about the nature of the [Copyright] Clause as a limitation [on government's power in allocation of information resources].").

157 Whitney v. California 274 U.S. 357, 373 (1927) (BRANDEIS, J., concurring) ("The right of free speech, the right to teach, and the right of assembly are, of course, fundamental rights.").

158 See Rose, supra note 124, at 330, 349; see also Cass R. Sunstein, On Property and Constitutionalism, 14 CARdozo L. REv. 907, 908 (1993) (“[P]roperty should be seen as a political right, one that reduces dependence on the state and creates the kind of security that is indispensable to genuine citizenship in a democracy."). But cf. Laura S. Underkuffler-Freund, Property: A Special Right, 71 Notre Dame L. Rev. 1033 (1996).

159 The conflicting judicial opinions regarding shopping mall cases demonstrate this point. In some cases, courts ruled against private owners of shopping malls and ordered the opening of malls for free speech activities. Pruneyard Shopping Ctr. v. Robins, 447 U.S. 74, 88 (1980); N.J. Coal. Against War in the Middle E. v. J.M.B. Realty Corp., 650 A.2d 757, 760-61 (N.J. 1994). Yet, courts also have ruled to the contrary on the basis that "property [does not] lose its private character merely because the public is generally invited to use it for designated purposes." Lloyd Corp. v. Tanner, 407 U.S. 551, 569 (1972); see also Wooley v. Maynard, 430 U.S. 705, 705 (1977); Hudgens v. NLRB, 424 U.S. 507, 521-23 (1976); Stranahan v. Fred Meyer, Inc., 11 P.3d 228, 244 (Or. 2000); W. Pa. Socialist Workers 1982 Campaign v. Conn. Gen. Life Ins. Co., 515 A.2d 1331, 1339 (Pa. 1986). 
speech values over the need to protect copyrights. ${ }^{160}$ Moreover, courts have ruled that copyright can actually trump the free speech right in certain cases. For example, in treating copyrighted works as the embodiment of their creators' speeches, the Supreme Court in Eldred v. Ashcroft held that the free speech value "bears less heavily when speakers assert the right to make [copyright holders'] speeches." ${ }^{161}$ This is because "although a message constitutes speech when the original speaker expresses it, it does not constitute speech when the copyist copies it." ${ }^{162}$

\section{Mainstreaming the Responsibility Policy into Copyright Law}

\section{a. The Role of the Responsibility Policy}

The responsibility policy would function to fill in the gap left by the Copyright Clause and the First Amendment. By infusing copyright holders' rights with responsibilities, copyright law would treat responsibilities as the quid pro quo for granting a bundle of exclusive rights to copyright owners. The responsibility policy would thereby provide a new policy consideration to help stakeholders of copyright protection (legislators, judges, copyright administrators, and copyright activists) rethink the function of copyright law. Copyright law would then function to ensure that creators with copyright protection would contribute to the public interest by improving the accumulation and dissemination of information and enhancing creativity and innovation in the economic and cultural development of society.

To carry out the responsibility policy, legislators and regulators should actively examine the extent to which responsibilities should be imposed on copyright holders. The past expansions of copyright protection, according to many commentators, were made primarily to benefit copyright holders' interests. ${ }^{163}$ These statutory expansions of copyright protection have facilitated

160 See David McGowan, Why the First Amendment Cannot Dictate Copyright Policy, 65 U. Pitt. L. Rev. 281, 295-96 (2004).

161537 U.S. at 221.

162 Christina Bohannan, Copyright Infringement and Harmless Speech, 61 Hastings L.J. 1083, 1116 (2010).

163 Litman, supra note 14, at 7 ("[In the past,] copyright lobbyists engaged in protracted negotiations with one another to arrive at copyright laws that enriched established copyright industries at the expense of both creators and the general public. There's ample reason to anticipate that the next copyright revision will proceed in similar fashion to similar ends."); Pamela Samuelson, Intellectual Property and the Digital Economy: Why the Anti-Circumvention Regulations Need to Be Revised, 14 BERKELEY TECH. L.J. 519, 523 (1999) ("[B]y colorful use of high rhetoric and forceful lobbying, Hollywood and its allies were successful in persuading Congress 
the convenience with which copyright holders can exploit their works or strengthen the exclusive rights bestowed on them. They have also imposed a greater burden on the public in their use of copyrighted works.

The orphan works problem demonstrates one way in which the failure to recognize a responsibility policy has negatively impacted copyright law. The problem refers to "the situation where the owner of a copyrighted work cannot be identified and located by someone who wishes to make use of the work in a manner that requires permission of the copyright owner." ${ }^{164}$ The British Library "estimates that over 40 percent of all in-copyright works are [o]rphan [w]orks." 165 To address this problem, the U.S. Copyright Office offered a proposal to legislatively restrict the remedies that copyright holders can seek if users are unable to locate the holder after first engaging in a "reasonably diligent search." 166 Yet, the proposal fails to consider the responsibilities that should be imposed on copyright holders to directly facilitate the resolution of this problem. After all, it is the copyright holder who has "abandoned" their works in the marketplace and has made it difficult for the user to locate him or her.

Because the copyright holderss abandonment causes the orphan works problem, one must consider whether such right holders have any responsibility to take part in problem-solving initiatives. The scrutiny over copyright holders' responsibilities is particularly important when legislators

to adopt the broad anti-circumvention legislation they favored, even if it is now subject to some specific exceptions that respond to some concerns raised by Silicon Valley firms and their allies in the legislative process.").

164 Marybeth Peters, U.S. Copyright Office, Report on Orphan Works 1 (2006), available at http://www.copyright.gov/orphan/orphan-report-full.pdf; see also Orphan Works, 70 Fed. Reg. 3739, 3739 (Jan. 26, 2005) (defining orphan works as those "whose owners are difficult or even impossible to locate"); see also Bernard Lang, Orphan Works and the Google Book Search Settlement: An International Perspective, 55 N.Y.L. SCH. L. REv. 111, 116 (2010-11) ("A work is said to be orphan when its rights holder cannot be identified or found, even after a diligent search, so that it is not possible to obtain a license for exploiting protected uses of the work."); Samuelson, supra note 7, at 483 (identifying orphan books as "books whose rights holders cannot readily be located. ...").

165 Orphan Works and Mass Digitisation, BRITISH LIBRARY, http://pressandpolicy. bl.uk/ImageLibrary/detail.aspx? MediaDetailsID=635 (last visited Jan. 30, 2013).

166 Marybeth Peters, U.S. Copyright OfFice, Report on Orphan Works 96 (2006), available at http://www.copyright.gov/orphan/orphan-report-full.pdf. For a detailed analysis of this proposal, see Denise Troll Covey, Rights, Registries, and Remedies: An Analysis of Responses to the Copyright Office Notice of Inquiry Regarding Orphan Works, in Free Culture and the Digital Library Symposium Proceedings 2005106 (Martin Halbert ed., 2005), available at http://works.bepress.com/denise_ troll_covey/45. 
consider proposals to enact or amend law to expand copyright protection or regulators make proposals to resolve copyright problems. Legislators and regulators should consider concrete policy implications of the three ethical justifications for copyright holders' responsibilities. They should examine how copyright holders should contribute to the creation and dissemination of their works. They should also pay sufficient attention to how any enhancement of copyright holders' rights would affect their role in shaping people's use of cultural power. Furthermore, they should scrutinize the extent to which any expansion of copyright protection would cause users negative distributive consequences, especially to those who use copyrighted materials for the purpose of teaching, news reporting, and research.

To ensure the effectiveness of the responsibility policy, legislators and regulators should require copyright lobbyists to analyze the relationship between copyright holders' responsibilities and their proposals to expand copyright protection. Copyright lobbyists would need to show that any expansions of copyright protection would be commensurate with the responsibilities that copyright holders owe to the public. After receiving briefings from lobbyists, legislators and regulators can then examine the relationship between copyright holders' responsibilities and any proposals to beef up copyright protection. If they find the relationship to be negative, then they should demand that lobbyists propose solutions to ensure that copyright holders would have adequate responsibilities.

Treating the responsibility policy as a new copyright policy would not mean displacing the Copyright Clause and the First Amendment as the policy basis for copyright law. Instead, the responsibility policy would fill in the gap left by the Copyright Clause and the First Amendment and buttress their policy mandates. First, the idea of responsibility would require the stakeholders of copyright protection to look beyond state actors to consider the impact of copyright holders on the protection of public interests. As discussed earlier, non-state actors such as copyright conglomerates have played a dominant role in shaping copyright law. ${ }^{167}$ However, as shown above, the Copyright Clause and the First Amendment do not apply to nonstate actors such as copyright holders. By contrast, the responsibility policy directly applies to copyright holders by requiring them to exercise their rights in responsible ways, with penalties for irresponsible acts. Moreover, it also requires state actors to make sure that copyright law is enacted and enforced with adequate measures to prevent copyright owners' irresponsible

167 Merges, supra note 154 , at 2236 (pointing out that the CTEA "was the Walt Disney Company's 'highest priority' in the 1998 legislative session of Congress.”). 
actions. Therefore, the responsibility policy targets both private actors (copyright holders) and state actors.

Second, the responsibilities imposed upon copyright owners would be concrete measures by which to facilitate Copyright Clause and First Amendment policy mandates, such as the promotion of "the Progress of Science and useful Arts" 168 and freedom of expression, respectively. Such responsibilities would require certain actions of copyright holders in order to realize those policy goals. For that purpose, the responsibility policy would require legislators and judges to think about why certain responsibilities should be imposed upon copyright holders, and further how those responsibilities ought to be enforced by copyright law.

Third, the responsibility policy would direct legislators and judges to make decisions that are faithful to the Copyright Clause and the First Amendment. As copyright holders would be required to act in responsible ways, their aggressive lobbying to strengthen copyright protection solely for their own interests would violate the ethics of responsibility. State actors who make legislative or administrative decisions that are skewed by those lobbying activities would violate the ethics of responsibility as well. Therefore, the responsibility policy would act as an ethical buttress to the Copyright Clause and the First Amendment, making them have stronger mandates for requiring socially desirable copyright legislation and regulation.

\section{b. Copyright Limitations as Copyright Holders' Responsibilities}

How should copyright law accommodate and enforce responsibility as a copyright policy? This section argues that copyright law can accomplish this goal by treating copyright limitations as the responsibilities imposed upon copyright holders. Such limitations already codified in copyright law include the fair use exception and the compulsory license scheme. Taking responsibility, as shown in the first section of Part II, means that parties cannot exercise their rights without due regard for the potential consequences to others.

In treating copyright limitations as responsibilities, they would no longer be treated as affirmative defenses to copyright infringement claims. ${ }^{169}$ Take fair use as an example. In a copyright dispute, a copyright holder (the plaintiff) first establishes a prima facie case for copyright infringement. A user (the defendant) can then invoke fair use as an affirmative defense. The

168 U.S. Const. art. I, $\S 8$, cl. 8 .

169 Sun, supra note 13 , at 134-42. 
user has the burden to prove that his use of the plaintiffs copyrighted work can constitute a fair use under Section 107 of the Copyright Act. ${ }^{170}$ However, treating fair use as an affirmative defense, as one of my earlier articles demonstrated, has "caused direct and indirect harms to public interests in free speech, democratic participation, and cultural development." ${ }^{171}$

Treating fair use as an affirmative defense is problematic because it only considers whether copyright holders' rights are infringed or not. If a user cannot prove the existence of fair use, he would be held liable for copyright infringement. This does not require judges to consider copyright holders' responsibilities or use them as the baseline policy factors.

Instead, the fair use analysis should be grounded in the premise that copyright holders must be required to take responsibilities to accommodate fair uses. It would transform a fair use case into a judicial inquiry about whether the copyright holder has taken the responsibility to accommodate fair uses. When a user-defendant invokes the fair use doctrine to negate the infringement claim raised by a plaintiff-copyright holder, the judge should require the copyright holder to bear the burden of proving that there is no fair use and therefore no need for accommodation.

Procedurally, the copyright holder should bear two burdens of proof. He first needs to prove that the user made unauthorized use of his work to establish the prima facie case of copyright infringement. He then needs to prove that the unauthorized use does not constitute fair use, if the user moves to rely on the fair use doctrine to negate his claim of copyright infringement.

Apart from the procedural function to shift the burden of proof, treating fair use as a responsibility imposed on copyright holders would require judges to examine the actions that copyright holders should take to accommodate fair uses. In particular, this responsibility-based fair use approach would be helpful for judges to decide difficult cases concerning fair use of copyrighted works, such as the Google Books Library Project case. Google was sued for copyright infringement after copying verbatim copyrighted works without authorization. It was very difficult for the court to decide whether or not the Google Book Library Project constitutes a fair use. This is because the court faced the exceedingly complex questions of whether Google's online indexing of books is a transformative use of works ${ }^{172}$ and the

${ }^{170}$ E.g., Campbell v. Acuff-Rose Music, Inc., 510 U.S. 569, 590 (1994) (ruling that " $[$ s $]$ ince fair use is an affirmative defense, its proponent would have . . . the burden of demonstrating fair use. ...”).

171 Sun, supra note 13 , at 152.

172 See Matthew Sag, The Google Book Settlement and the Fair Use Counterfactual, 55. N.Y.L. SCH. L. REV. 19, 27-31 (2010). 
project may affect copyright holders' marketing of similar digital library services. ${ }^{173}$ To resolve such questions, the court must examine whether copyright holders have any specific responsibilities to accommodate fair use. The identification of copyright holders' responsibilities, as the following discussion will show, is a judicial process to specify the public interests involved in fair use cases.

The court may first maintain that copyright holders have the responsibility to accommodate the public's collective right to cultural participation and to benefit from technological advances. Through the technology advanced by Google, the public can obtain "basic bibliographic information" about the works and use the "search term" to locate relevant contents. ${ }^{174}$ These are informational resources located in the public domain and not subject to copyright protection. Having access to and use of them are of essential importance for the public to enjoy its rights. For example, the Project aids cultural participation by helping researchers and teachers locate the information they need. Although, verbatim copying by Google is necessary to help the public enjoy these rights in a meaningful way, the court should also note that Google has taken measures in order to prevent or minimize the potential harm to the copyright holders. For example, it only shows snippets of the works to the public, displays copyright notices, and links the public to the pages from which they can purchase the works.

Second, the court may further maintain that copyright holders have the responsibility to accommodate the public in exercising their collective right to protection of our cultural ecosystem. Digital technology opens a myriad of opportunities to archive works by digitizing them. It facilitates and enhances our cultural ecosystem by reducing the cost for the public to use works and enriching the diversity of works available to the public. ${ }^{175}$ From this perspective, copyright holders must participate in the digital technology-based protection of our cultural ecosystem by allowing digital archiving that is being carried out by the agent, such as Google. Since Google is a forprofit organization, the court may require it either to donate a reasonable portion of its Project revenues to non-for-profit public interest organizations, or to reasonably compensate copyright holders for their involvement in the project.

Yet it does not necessarily follow that courts should invoke the responsibility policy in every case that examines whether copyright holders should

173 See Sag, id. at 33-36.

174 Google Books Library Project, GoogLE, www.google.com/googlebooks/library.html.

175 See, e.g., Zimmerman, supra note 6, at 993-97. 
accommodate the public interest. This mode of adjudication may render many conventional copyright doctrines dysfunctional in dealing with private law suits. Instead, courts should use the responsibility policy analysis as a last resort. Only when courts find it difficult to make a decision after using conventional doctrinal tools should they use the responsibility policy analysis. In this context, courts can draw on the responsibility policy analysis to consider whether, and to what extent, the copyright holder has social responsibilities to the public.

\section{B. Promoting the Ethics of Responsibilities among Copyright Holders}

The preceding section discussed ways in which copyright law can help the three branches of the government enforce responsibilities upon copyright holders. Adopting the responsibility policy would broaden the spectrum of policy considerations that legislators and regulators must make. Defining copyright limitations as copyright holders' responsibilities would also help judges make socially sound decisions that accommodate diverse public interests in the production and dissemination of copyrighted works.

The responsibility policy is designed to guide public institutions, namely the three branches of the government, in protecting copyrights. The two conceptions of responsibility discussed in the following two sections play a different role. Negative responsibilities and collective responsibilities are designed to guide private parties, namely copyright holders, with the ethical conduct code. Section 1 canvasses the legal rules that can enforce copyright holders' negative responsibilities, help overcome individualism in copyright protection, and facilitate copyright holders' role in shaping users' cultural power. Section 2 discusses the issues that must be addressed before actually enforcing copyright holders' collective responsibilities concerning the promotion of social justice.

\section{Negative Responsibilities}

Copyright holders' responsibilities take two forms: negative and positive. Negative responsibilities limit copyright holders to exercising their rights in ways that do not harm users' legitimate interests in making use of copyrighted works. ${ }^{176}$ By contrast, positive responsibilities require copyright

176 For the idea of negative responsibility, see Thomas W. Pogge, World PovERTY AND HumAN Rights: COSMOPOLITAN RESPONSIBILITIES AND REFORMS 131 (2002); H. M. Malm, Directions of Justification in the Negative-Positive Duty Debate, 27 Aм. PHIL. Q. 315, 315 (1990) ("Let us refer to duties not to cause harm as negative duties, and to duties to prevent harm as positive duties."). 
holders to take affirmative actions to promote and protect users' legitimate interests. ${ }^{177}$ Because such affirmative actions may impose too heavy a burden on copyright holders, I propose that negative responsibilities are a more viable solution.

\section{a. The Basis of Negative Responsibilities}

Negative responsibilities apply to two types of uses of copyrighted works by the public. The first type of use causes no harm to copyright holders, while the second type causes them minor harm. In the former situation, negative responsibilities should require copyright holders to accommodate such harmless unauthorized uses. ${ }^{178}$

A wide range of private uses cause no harm to copyright holders: a person emails an academic article to his colleague, makes a copy of a film and sends it to his family to ask for their comments, or records a TV program to watch at a later time. In all of these cases, no harm is caused to copyright holders. Moreover, a wide range of uses of copyrighted works in the public setting theoretically do not cause harm to copyright holders, such as a public performance of a copyrighted song in a church service, or the use of a short clip of a film in a public presentation to illustrate a viewpoint.

Copyright holders' negative responsibility to allow harmless uses of their works is first justified by their role responsibility and the reciprocity principle, as discussed in Part II. The reciprocity principle requires copyright holders to make appropriate contributions to the promotion of the public interest because they benefited from prior works made available to the public when they created their works. For example, the consumer of a new article, film, or television program (in private-use cases) may use new information therein to develop a new research project, write new film comments, or learn about social and political issues reported by media. Such uses

177 For the idea of positive responsibility, see Pogge, supra note 176, at 131.

178 Based on the free speech values, Professor Christina Bohannan suggests copyright law should accommodate harmless use. Bohannan points out that "[a]lthough the First Amendment sometimes protects even harmful speech, it does not allow the prohibition of harmless speech." Bohannan, supra note 162, at 1085 . Therefore, "given the speech value inherent in all kinds of copying, copyright law must be subject to the same harm requirement as other forms of speech regulation." Id. at 1087. Moreover, Professor Wendy Gordon has argued similarly, but her argument is based on a law and economics perspective rather than the ethical perspective discussed in this article. Wendy J. Gordon, Keynote Address, Harmless Use: Gleaning from Fields of Copyrighted Works, 77 FordHAM L. REv. 2411, 2434 (2009) (" $[\mathrm{C}$ ]opyright law should give more honor to harmless uses-uses that produce results that are Pareto superior to nonuse."). 
have the effect of disseminating the substance of copyrighted works to audiences that the copyright holders do not intend to reach.

Second, copyright holders, as discussed in Part II, need to fulfill their role responsibilities to nurture fellow citizens' cultural power to discuss and critique social issues. The reason for encouraging dissemination of copyrighted works must be the hope that they will be consumed, that is, processed or considered. It is only through consumption of works that copyright law can enhance the marketplace of ideas and democratic governance. A good deal of copying must be done in the process of this consumption. ${ }^{179}$ As Rebecca Tushnet has argued, copyrighted works permeate human life, profoundly influencing social and political views. Thus, she has pointed out that "when moments of political choice do come, our responses are shaped by the culture around us. As a result, freedom to participate in shaping culture is an overriding concern of the democratic self-governance view [of the First Amendment]." ${ }^{180}$ Similarly, Eugene Volokh has emphasized that in many cases of copyright infringement, the copied "work is materially more valuable to readers than the original that they can't get, that costs too much, or that they don't know about." 181

All these uses of copyrighted works are largely harmless to copyright holders because users do not come into any direct or indirect competition with copyright holders. Uses of copyrighted works, either in private or public settings as discussed above, do not reach the market in which copyright holders issue licenses and charge royalties for others to use their works.

\section{b. The Enforcement of Negative Responsibilities}

Copyright limitations should be designed to adequately enforce copyright holders' negative responsibilities. Otherwise, copyright holders may ignore their responsibilities and gain unfettered control over harmless uses of their works. They may do so by simply claiming that their copyrights entitle them to authorize (or prevent) any uses of their works by others.

179 Davis v. Gap, Inc., 246 F.3d 152, 173 (2d Cir. 2001) ("Most honest citizens in the modern world frequently engage, without hesitation, in trivial copying that, but for the de minimis doctrine, would technically constitute a violation of law.").

180 Rebecca Tushnet, Copy This Essay: How Fair Use Doctrine Harms Free Speech and How Copying Serves It, 114 YALE L.J. 535, 540 (2004).

181 Eugene Volokh, Freedom of Speech and Intellectual Property: Some Thoughts After Eldred, 44 Liquormart, and Bartnicki, 40 Hous. L. REV. 697, 726 (2003). 
Without their authorization, harmless use still amounts to an infringement of copyright. ${ }^{182}$

The fair use doctrine codified in Section 107 of the U.S. Copyright Act does not contain effective safeguards to enforce negative responsibilities. The problem largely stems from the treatment of fair use as an affirmative defense. First, under the affirmative defense mode of fair use, a user has the burden of proving he or she did not harm the copyright holder's market. ${ }^{183}$ Copyright holders do not need to prove the existence of harm to their market when they establish the prima facie case for copyright infringement. Therefore, it is procedurally and economically easy for copyright holders to sue users whose uses are harmless to copyright holders' markets. The burden of proving the absence of market harm is troublesome for users, as it is not easy for them to obtain data about copyright holders' market and examine the market impact of their uses on copyright holders. This asymmetry between copyright holders and users concerning the burden of proof may deter users from making fair uses of works even though they are harmless to copyright holders.

An additional barrier to enforcement is the fact that courts have deemed the market value of the copyrighted work as one of the most important factors weighing against fair use, and yet have broadly defined the scope of copyright holders' markets. In Folsom v. Marsh, a decision regarded as the origin of the modern fair use doctrine, Justice Story emphasized the finding of the actual harm to copyright holders in fair use cases, because liability only turns on "the degree in which the use may prejudice the sale, or diminish the profits, or supersede the objects, of the original work." 184 The market value was later codified in Section 107 of the Copyright Act as the fourth factor of the fair use analysis. Courts have regarded this factor as most important in the fair use analysis. ${ }^{185}$ By hailing the "market value" factor as

182 See Jessica Litman, Lawful Personal Use, 85 Tex. L. Rev. 1871, 1898 (2007) ("The conventional analysis would tell us that when those uses involve a fixed reproduction, an adaptation, or a public distribution, performance, or display, then they infringe copyright unless they are excused by the fair use privilege codified in $\S 107 . ")$.

183 See Sun, supra note 13, at 134-42.

1849 F. Cas. 342, 348 (C.C.D. Mass. 1841) (No. 4901).

185 See Harper \& Row, Publishers, Inc. v. Nation Enters., 471 U.S. 539, 566 (1985) (finding that the effect on the market is "undoubtedly the single most important element of fair use."); Princeton Univ. Press v. Mich. Document Servs., Inc., 99 F.3d 1381, 1385 (6th Cir. 1996) ("We take it that . . 'the effect of the use upon the potential market for or value of the copyrighted work,' is at least primus inter pares . . . ."); see also Barton Beebe, An Empirical Study of U.S. Copyright Fair Use Opinions, 1978-2005, 156 U. PA. L. REV. 549, 617 (2008) (“59.0\% of the opinions 
"undoubtedly the single most important element of fair use," ${ }^{186}$ Harper $\mathcal{E}$ Row foreclosed fair use by primarily weighing the individual interest in accessing and using works against the copyright holder's economic interest in the marketability of their works. ${ }^{187}$ Therefore, the Harper $\mathcal{E}$ Row decision ignored the fact that the defendant's quoting three hundred to four hundred words of the former president's manuscript was vital to lending authenticity to its reporting on the resignation and pardon of former president Richard Nixon. Keeping the public informed of the details of that historical event undoubtedly "furthered the public interest" 188 in "[a] broad dissemination of principles, ideas, and factual information [that] is crucial to the robust public debate and informed citizenry." 189

Following the responsibility policy, the consideration of copyright holders' negative responsibilities must become part of fair use analysis, especially as part of the fourth factor about the use's impact on the copyright holder's market. Courts should allow uses of works that would cause no harm to copyright holders' market and justify such uses on the grounds that copyright holders have negative responsibilities to allow the public to make these types of uses.

\section{Collective Responsibilities}

Copyright law should also promote copyright holders' collective responsibilities. In contrast to negative and positive responsibilities that are attributed to the copyright holder on an individual basis, collective responsibilities require all copyright holders to share common burdens. Responsibilities of this kind are collective because copyright holders are regarded as sharing two kinds of common identities: first, as social members who receive benefits from social cooperation for copyright protection; second, as social members who perform the role of shaping people's cultural power. These two common identities, to a certain degree, make the relevant responsibilities imposed on copyright holders collectively sharable. Copyright holders should collectively take responsibility to bear the burdens of social coopera-

following Harper $\mathcal{E}$ Row (but preceding Campbell) explicitly cited [the fact that the Supreme Court declared the effect of use on the market as the most important factor] .... Of the opinions following Campbell, 26.5\% continued explicitly to state that factor four was the most important factor.").

186471 U.S. at 566.

187 Through this emphasis on the protection of the copyright holder's economic interest, the Court applied "an exceedingly narrow definition of the scope of fair use.” Id. at 579 (Brennan, J., dissenting).

188 Id. at 591.

189 Id. at 582. 
tion for copyright protection in proportion to the benefits they receive from this system.

Copyright holders' collective responsibilities take two forms. The first type of responsibilities are concerned with accommodating uses of copyrighted works that are permissible under copyright limitations, such as the fair use exception and first-sale exception. This collective responsibility deals only with the relationship between copyright holders and state institutions, including Congress, courts, and the Copyright Office. When these state institutions offer a legitimate reason for expanding the scope of copyright limitations, all copyright holders have the responsibility to bear the extra burden to allow the public to use their works within the expanded scope of copyright limitations.

The second collective responsibility is the responsibility to reconsider the relationship between the market in exploiting works and the public interest. Copyright holders are accustomed to treating their exclusive rights as marketable rights, which means that it is through the license-and-payment transactions in the marketplace that they maximize the commercial value of their works. They hail the market as the panacea for curing a host of public goods problems. Under this rubric, clearly defined rights to exclude are taken for granted as the core element of copyright law. ${ }^{190}$ Those copyright doctrines that protect exclusive rights have been shaped by these theories. For example, the Supreme Court stated in Bleistein v. Donaldson Lithographing Company that the sole measure of quality in copyright law is the market's willingness to pay. ${ }^{191}$ In the Court's words, "if they command the interest of any public, they have a commercial value-it would be bold to say that they have not an aesthetic and educational value - and the taste of any public is not to be treated with contempt." 192 This approach foregrounds a voluntary author-audience exchange for money. It makes the sale of copyrighted works in the marketplace both normal and good.

However, copyright holders should take responsibility to consider how and why the market-based mode of exploiting copyrighted works may cause social inequalities. According to Robert Hale, the so-called "free market" is by no means free of coercion; rather, the property-based coercive power is immanent in the marketplace. While every person has an equal nominal

190 Assessing the Economic Impact of Copyright Reform on Authors, Makers, Photographers and Publishers in Canada in Reference to Two New Copyright-Related Treaties, available at www.ic.gc.ca/eic/site/ippd-dppi.nsf/eng/ip01141.html (pointing out that "a well functioning market for copyrights requires that those copyrights be clearly defined, affirmed and enforced").

191188 U.S. 239 (1903).

192 Id. at 251. 
status as a trading participant in the marketplace, the type and amount of resources that they control, in fact, differ from one person to another. Therefore, the bargaining power they have when negotiating deals in the marketplace always varies from person to person, making it possible that people with stronger bargaining power can coerce others into following their commands. ${ }^{193}$

In this context, one of the pressing issues copyright holders should collectively consider is whether they should take the responsibility to accommodate or even promote the user-based and open access-oriented modes of innovation, which have flourished in the digital age. ${ }^{194}$ The free software movement, the Creative Commons initiative, and a series of new media projects like Wikipedia and YouTube all challenge the conventional ways of exploiting copyright that put the copyright holder on the top of the information hierarchy. These movements have generated sharp criticisms of, and creative alternatives to, the conventional model of copyright protection.

It is worth noting that the first type of copyright holders' collective responsibilities should be legally enforceable. This means that it is a legal responsibility. If a copyright holder refuses to accommodate public uses of his works permissible under the expanded scope of copyright limitations, he would be held legally liable for misusing his copyright. In this scenario, the copyright misuse doctrine ${ }^{195}$ can be invoked to penalize the copyright holder concerned. By contrast, the second type of copyright holders' collective responsibility is a non-legally enforceable moral responsibility. It follows that copyright holders would not be legally penalized if they fail to consider the viability of open-access modes of generating innovation and take measures to accommodate them. However, copyright holders may be morally at fault for their failure to adapt to changing circumstances by promoting open access and ameliorating social inequalities.

193 See Robert L. Hale, Coercion and Distribution in a Supposedly Non-Coercive State, 38 Pol. SCI. Q. 470 (1923).

194 See generally Yochai Benkler, Coase's Penguin, or, Linux and The Nature of the Firm, 112 YALE L.J. 369 (2002); William W. Fisher III, The Implications for Law of User Innovation, 94 MiNN. L. REv. 1417, 1418-23 (2010); Rochelle Cooper Dreyfuss, Does IP Need IP?: Accommodating Intellectual Production Outside the Intellectual Property Paradigm, 31 Cardozo L. Rev. 1437, 1443-1447 (2010).

195 See, e.g., Lasercomb America, Inc. v. Reynolds, 911 F.2d 970, 978 (4th Cir. 1990) (holding that if the right holder uses his copyright "in a manner adverse to of the public policy embodied in copyright law," his conduct would amount to copyright misuse). 


\section{Conclusion}

We live in an age of irresponsibility. ${ }^{196}$ The prevalence of the commercial culture in our contemporary society compels many people to relentlessly pursue their own interests. There are fewer and fewer people who may take their responsibilities as seriously as John D. Rockefeller Jr. did decades ago. He said that he "believe[d] that every right implies a responsibility; every opportunity, an obligation; every possession, a duty." 197

This Article reveals that the traditional mode of copyright protection has bred a widespread irresponsibility mentality among many copyright holders. To address this problem, this Article calls for the integration of responsibilities in copyright law as a quid pro quo for granting exclusive rights to copyright holders.

The imposition of responsibilities on copyright holders, however, is not intended to undermine their creative inputs or to appeal for "the death of authors." ${ }^{198}$ Instead, it is designed as an ethical initiative to foster and promote a more creative and dynamic way to interpret the nature of copyrights. This ethical initiative still champions the cause for copyright protection as a means of securing self-actualization for authors, as expressed in Virginia Woolf s call that "a woman must have money and a room of her own if she is to write fiction." 199

Meanwhile, the ethics of responsibility further highlights the need for copyright holders to recognize the socially-conditioned nature of the creation and dissemination of their copyrighted works, to reimagine their proper roles in shaping people's cultural power, and to rethink any social inequalities that copyright protection may bring about. This requires copyright holders, legislators, regulators, and judges to engage in deliberating about these ethical issues.

If the language of rights opens the avenue for each individual to pursue freedom and self-actualization on their own, the language of responsibilities intends to guide each individual to explore collectively the greatness of being a social member for the common good of society. In the context of copyright law, the language of responsibility would function to unite copyright holders with users of copyrighted works to reimagine the role of copy-

196 See generally VeITCH, supra note 29; IRIs Marion Young, Responsibility FOR JUSTICE 25 (2011) ("Many relatively privileged people behave irresponsibly in all kinds of ways.")

197 Robert T. Grimm, Notable American Philanthropists: Biographies of GIVING AND VOLUNTEERING 265 (2002).

198 See generally Barthes, supra note 121.

199 Virginia Woolf, A Room of One's Own 4 (2001). 
right law in the digital age. It is an age in which the ethics of responsibility should be hailed an intrinsic human value that undergirds copyright law. Therefore, the law's embracement of copyright holders' responsibilities with their rights would serve as the path through which people can act in concert and then make wonders for the continuity of human civilization. ${ }^{200}$

200 Hannah Arendt, On Violence 44 (1970) ("Power corresponds to the human ability not just to act but to act in concert. Power is never the property of an individual; it belongs to a group and remains in existence only so long as the group keeps together.”). 
